\title{
MaAREVISJONid Eesti- JA LIIVIMAAL ROOTSI VÕIMUPERIOODI ALGUSES
}

\author{
Ülle Tarkiainen
}

Maarevisjonid on Eesti asustus- ja agraarajaloo tähtsamateks allikateks Rootsi võimu perioodist. Nendes sisalduvat informatsiooni on kasutatud arvukates uurimustes ja see pilt, mis meil on elanikkonna ja asustuse struktuuri ning selle muutumise, läänistamiste, talurahva koormiste ning põllumajandusolude kohta eri piirkondades, põhinebki peamiselt Rootsi Riigiarhiivi Kammerarhiivis, Ajalooarhiivis Tartus ja Läti Riiklikus Ajalooarhiivis säilitatavatel revisjonide materjalidel. Rootsi Riigiarhiivis hoiul olevad Eesti ala revisjonid on avaldatud ka allikapublikatsioonidena - suurem osa Oleg Roslavlevi poolt - ja see on nende allikate kasutusvõimalusi tunduvalt avardanud. ${ }^{1}$

Vähe tähelepanu on aga pööratud küsimustele, kuidas revisjonid toimusid ja milliseid eesmärke püüdsid Rootsi võimud nende abil Eesti- ja Liivimaal saavutada. ${ }^{2}$ Vastust viimasele küsimusele võib pidada suures osas enesestmõistetavaks, sest enamasti on ju revisjone läbi viidud kroonu

Artikkel on valminud sihtfinantseeritava teema nr SF01800o6s11 ja Eesti Teadusfondi grandi nr 8209 raames.

1 Liivimaa 1638. a. maarevisjon: Eesti asustusala I: kaguosa, ENSV Riigi Keskarhiivi Tartu osakonna Toimetused, 1 (7) (Tartu, 1941); Das Dorpater Land 1624/27, Hefte zur Landeskunde Estlands, 1, hrsg. von Oleg Roslavlev (München, 1965); Das Pernauer Land 1624, Hefte zur Landeskunde Estlands, 2, hrsg. von Oleg Roslavlev (München, 1967); Die Revision Livlands 1601: Estnisches Siedlungsgebiet, Hefte zur Landeskunde Estlands, 3, hrsg. von Oleg Roslavlev (München, 1967); Die Revision Livlands 1638. Estnisches Siedlungsgebiet 2, Hefte zur Landeskunde Estlands, 4, hrsg. von Oleg Roslavlev (München, 1969).

2 Eesti ala kohta vt Arvi Korhonen, "Michel Jordan", Ajalooline Ajakiri, 3 (1935), 97-118; Arvi Korhonen, "Rootsi revisjon Baltimail 1601. aastal", Ajalooline Ajakiri, 1 (1926), 1-22; Aadu Must, Eestlaste perekonnaajaloo allikad (Tartu: Kleio, 200o), 229-232. Läti ala kohta on olemas väga põhjalikud uurimused: Arveds Švābe, Die älteste schwedische Landrevision Livlands (1601), Latvijas Universitātes Raksti. Tautsaimniecības un tiesību zinātṇu fakultātes serija, II:3 (Rigā: Latvijas Ūniversitāte, 1933); Edgars Dunsdorfs, Vidzemes arklu revizijas 1601.-1638, Latvijas Universitātes Raksti. Tautsaimniecības un tiesību zinātṇu fakultātes serija, IV:1 (Rigā: Latvijas Ūniversitāte, 1938); Edgars Dunsdorfs, Actus Revisionis Livoniae 1638: Pars Latviae: Fasc. I, Fontes Historiae Latviae, IV, Editio Institute Historiae Latviae (Riga, 1938). 
tulude planeerimiseks, väljaselgitamiseks ja täpsustamiseks. Siiski vääriks põhjalikumat käsitlemist see, millist informatsiooni eri revisjonides kirja pandi ning milline on olnud revisjoni-institutsiooni üldine areng Eesti- ja Liivimaal. Jälgimist vajab ka maarevisjonide asetumine eri perioodidele, sest just ajastatus seob neid Rootsi üldise majanduspoliitikaga, kusjuures tähelepanu peab pöörama revisjonide omavahelistele seostele ning sõltuvusele ajastu teistest nähtustest. Revisjonide läbiviimise tehniline pool on jäänud üldiselt kirjeldamata, kuigi selle kohta on allikmaterjalis üsna palju informatsiooni. Ka on vähe uuritud revisjonide ilmset seost läänistamisega.

Käesolev uurimus keskendub seetõttu revisjonide probleemi käsitlemisele veidi teisest vaatenurgast, kui on olnud tavaline. Vaatluse alla on võetud 16. sajandil Eestimaal ning 17. sajandi esimesel poolel Eestimaal ja Liivimaal toimunud revisjonide läbiviimise põhjused ja eesmärgid. Erilist tähelepanu on pööratud revisjonide läbiviimise protsessile: nii ajalistele raamidele, meetoditele kui ka tegijatele, aga ka Rootsi majandusliku valitsemise üldistele eesmärkidele. On oluline märkida, et õige maarevisjon (jordrevision, mõnikord rannsakning või sellele vastav väljend) eeldas enamasti kuningliku komisjoni määramist. Ilma kuninga volituseta ei saanud kohalikud ametnikud ulatuslikku revisjoni läbi viia.

Kui mitmesuguseid piirkondlikke (enamasti mõisate) vakuraamatuid koostati koormiste määramiseks ning maavalduse muude sisemiste vajaduste tarbeks pidevalt, siis põhjalikke, valitseja käsul tehtud revisjone koostati vaid üksikuid. Rootsi võimu algperioodil Eesti- ja Liivimaal läbi viidud ulatuslikumad revisjonid toimusid aastatel 1586-9o Eestimaal ja 1600-01 Eestimaal ja Liivimaal, lisaks 1624-27 ning 1638 Liivimaal. Peale nende toimus veel mitu väiksema ulatusega revisjoni, mis jäid kas pooleli või mille tulemused on sälinud ainult osaliselt (1617.-19. ja 1630. aasta revisjonid). Revisjonide materjalid saadeti Stockholmi kuninglikule arvekojale (1634. aastast kammerkolleegiumile) ja need jäidki sinna. Aja jooksul nende praktiline väärtus kadus ning erinevalt kartograafilistest materjalidest revisjonidokumente pärast 1721. aastal sõlmitud Uusikaupunki rahu Venemaale ei loovutatud.

\section{Rootsi riigi maksusüsteem}

Teema seisukohalt on oluline esmalt kirjeldada Rootsi maksusüsteemi eripära võrreldes Läänemere provintsides varem valitsenud oludega. Rootsi majandushalduse süsteem sündis kuningas Gustav Vasa valitsusajal (152160), pärast seda, kui riik oli löönud lahku Kalmari unioonist. Majanduslik 
valitsemine ja maksusüsteem kujunesid 1540. aastatel välja peamiselt Saksa vürstiriikide eeskujul. Rootsi oli 16. sajandil seisuslik ühiskond, mis sai märkimisväärse osa tuludest põllumajandusest, kus mängisid võtmerolli maaomandisuhted. Umbes pool haritavast maast oli iseseisvate maksutalupoegade (skattebönder) valduses, samas kui ligi kolmandik maast oli kirikumaade riigistamise järel kroonu käes: seda harisid kroonutalupojad (kronobönder). Ülejäänud talud kuulusid aadlimõisatele, mida kasutasid aadlitalupojad (frälsebönder) ja vabadikud (frälselandbon). ${ }^{3}$ Geograafiliselt vaadatuna asus enamik iseseisvaid maksutalupoegi Rootsi põhjaosas ja Soomes, aadlike maid oli rohkem Rootsi kesk- ja lõunaosas. Seega erinesid Rootsi põhialade maaomandisuhted Läänemere provintsidest, kus maa oli enamasti kohalike aadlike käes ja talupojad kuulusid peaaegu täielikult mõisate alla.

Gustav Vasa loodud riik vajas eri ülesannete täitmiseks hulgaliselt enamasti aadliseisusest sõjaväe- ja tsiviilametnikke. Ametimehed said naturaalmajanduse tingimustes palka tavaliselt nii, et neile läänistati kroonutalupoegade maksud, mis läksid seega aadlike ülalpidamiseks, mitte enam riigikassasse. Läänistused haarasid enamasti üksikuid talusid ja peaaegu mitte kunagi suuremaid alasid, näiteks terveid külasid, ning nendega kaasnes maksude sissenõudmise õigus, aga mitte administratiivseid kohustusi või kohtuvõimu - need jättis riik enda kätte. Läänistused ei olnud päritavad, vaid anti ajutiselt (tills vidare) või eluajaks (för livstid).

Läänistustest erinesid põhimõtteliselt kingitused ehk donatsioonid, mis kulgesid aadliku suguvõsas pärandina. ${ }^{4}$ Riik hakkas neid jagama 16. sajandi teisel poolel ja põhjuseks oli asjaolu, et kuningavõim oli muutunud 1540. aastatel pärilikuks, seega pidi ka aadlivõim olema osaliselt päritav. Donatsioone anti vaid riigi kõrgeimatele ametimeestele ja neidki karmidel tingimustel, enamasti vastavalt Norrköpingi otsustele. See 1604. aasta riigipäeval kinnitatud donatsiooni vorm tähendas, et mõis pärandati meesliinis isalt pojale, ja juhul, kui suguvõsa meesliinis katkes, läks valdus riigi kätte tagasi. Kõik läänistused ja donatsioonid olid Rootsis põhimõtteliselt sellised, et nendest sai loobuda ja need võisid ilma takistuseta minna tagasi riigile. Siin olid aluseks eelkõige keskaegsed maaseadused, milles rõhutati,

\footnotetext{
3 Vt Janken Myrdal, Jordbruket under feodalismen 1000-1700, Det svenska jordbrukets historia (Stockholm: Natur och kultur/LTs förlag, 1999), 323-338.

4 Läänistamise kohta vt Aleksander Loit, Kampen om feodalräntan: reduktionen och domänpolitiken i Estland 1655-1710, I, Acta Universitatis Upsaliensis, Studia Historica Upsaliensia, 71 (Uppsala, 1975), 42-64; Herbert Ligi, Talupoegade koormised Eestis 13. sajandist 19. sajandi alguseni (Tallinn: Eesti Raamat, 1968), 14-26; Jürgen Heyde, Bauer, Gutshof und Königsmacht, Quellen und Studien zur baltischen Geschichte, 16 (Köln, Weimar, Wien: Böhlau, 200o), 98-106.
} 
et kuningas ei saanud riigi omandit vähendada. Lisaks oli määratud, et mõisa omaniku vahetudes pidi uus mõisnik taotlema oma õiguste kinnitamist valitseja poolt. Johan III ajal 16. sajandi lõpul oli feodalism arenenud Rootsis Mandri-Euroopa eeskujul juba nii kaugele, et kuningas hakkas jagama eriti teenekatele kõrgaadlikele krahv- ja vabahärrakondi - suuri alasid, kus valdajatel oli lisaks maksude sissenõudmise õigusele ka kohtuja haldusvõim. Ulatuslikumaks muutus see alles 1640. aastatel kuninganna Kristiina eestkostevalitsuse ajal. ${ }^{5}$

Maksustamine oli Rootsis 1540. aastatest alates korraldatud foogtkondade kaupa. Kogu maa - ka aadlimaa - oli jagatud foogtkondadeks, mis haarasid tavaliselt ühe kihelkonna territooriumi ja mille keskus oli kroonu loss või kuninga mõis. Foogtkonna eesotsas oli foogt, kes kogus abiliste toel riigimakse ja esitas nende kohta igal aastal Stockholmis aruande. Maksuraamatusse tehti märge ka läänistatud kroonumaksude kohta, mis enam riigile ei läinud. Foogtid olid mitteaadlikest ametnikud, keda sagedasti välja vahetati ja kellel võis lisaks maksude kogumisele olla ka muid halduslikke või sõjalisi ülesandeid. Kedagi ei nimetatud foogtiks oma kodukanti ja et vähendada krooni petmise võimalusi, ei saanud keegi kaua foogti ametis olla. ${ }^{6}$

Riigi tulude ja kulude haldamise keskseks organiks oli 1539.-40. aastal sisse seatud arvekoda (kammaren) koos oma osakondadega, milleks olid arvekamber (räknekammaren) ja maksukamber (räntekammaren). Arvekoja osakondadel ei olnud oma kantseleid: nende kirjavahetus saadeti otse ametnikele või registreeriti kuninglikus kantseleis kuni 1634. aastani, mil moodustati arvekoja alusel iseseisev amet - kammerkolleegium. Arvekoda paiknes Stockholmis kuningalossis, kuid teatud aegadel prooviti ka kohalikku majandushaldust. Nii tegutses Tallinnas 1560. aastatel sõjakulusid registreerinud koda ja Soomes tekkis 1571. aastal oma arvekoja osakond.?

Arvekojal oli mitu riigi majandus- ja rahandushaldusega seotud ülesannet. Majandusalase koolituse saanud ametnikud registreerisid foogtide poolt esitatud kontseptilaadsed aruanded maksude sissenõudmise kohta maakondade kaupa nn foogtiarveteks ja kirjutasid nende põhjal

\footnotetext{
5 Eino Jutikkala, Suomen talonpojan historia, Suomalaisen Kirjallisuuden Seuran Toimituksia, 257 (Helsinki: Suomalaisen Kirjallisuuden Seura, 1958), 138-140.

6 Johan Axel Almquist, Den civila lokalförvaltningen i Sverige 1523-1630 med särskild hänsyn till den kamerala indelningen, 1-4, Meddelanden från svenska Riksarkivet, ny följd II, 6:1-4 (Stockholm, 1917-1923), 112-113, 117.

7 Jan Brunius, Vasatidens samhälle: en vägledning till arkiven 1520-1620 i Riksarkivet, Skrifter utgivna av Riksarkivet, 32 (Stockholm, 2010), 120.
} 
riigi majandusest aruande. ${ }^{8}$ Maksud märgiti igal aastal maaraamatusse (jordebok, årliga räntan), kuhu pandi miinuspoolele kirja ka läänistatud aadlimaa sissetulek. Maaraamatus loetleti talupojad talude kaupa vastavalt maa liigile (maksu-, kroonu- ja aadlimaa eraldi) ja tavaliselt pandi kirja ka talu suurus adramaades (mantal) ning sellel lasuvad koormised. Talupojad tasusid iga-aastaseid koormisi enamasti naturaalandamina, millele

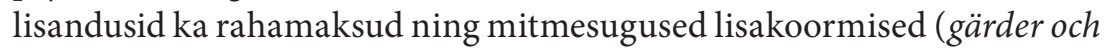
hjälper). Nendele liideti veel kirikule makstav kümnis (tionden) ja trahvid (sakören). Lisaks kuulus foogtiarvete juurde selgitus foogtkonna kulude kohta (utgiften), millest ilmnes, kuidas foogtkonna varasid oli kasutatud. Iga väljaminek pidi olema kinnitatud kviitungiga (verifikation). ${ }^{9}$ Rootsi majanduslik raamatupidamine oli üldiselt väga täpne.

Maksustamise aluseks oli ülevaatus, millega kaasnes esimene maksustamine (skattläggning või rannsakning). Hiljem kanti nõutavad koormised mehaaniliselt ühest maaraamatust teise. Maksude muutmine oli vältimatu, kui asustuses toimusid olulised muutused, kuid see ei toimunud mitte jooksvalt, vaid perioodiliselt. Koormised, mis põhinesid üldiselt aastate jooksul samaks jäänud talude adramaade arvul, olid oma iseloomult muutumatud ja püsivad.

\section{Rootsi majandushaldus Eestimaal}

Kui Eestimaa langes Rootsi võimu alla, pidid Rootsi foogtid ja foogtikirjutajad hakkama tegutsema alal, kus valitsesid teistsugused majandusolud ja võimusuhted kui emamaal. Kuningas Erik XIV saadikud võtsid Tallinnas 6. juulil 1561 vastu Harju-, Viru- ja Järvamaa aadlike ustavusvande ja kinnitasid nende privileegid, mille kuningas ratifitseeris Norrköpingis 2. augustil 1561. Aadel säilitas õigused, privileegid, vabadused ja vanast ajast kehtinud tavad. ${ }^{10}$ Nende hulka kuulus ka kohtuvõimu kasutamine aadli valdustes. Vastavalt privileegidele olid aadlikud maksudest vabastatud ja seetõttu ei olnud kroonu maksuametnikel päritud aadlivaldustesse asja muul põhjusel kui ainult nende läänikirjade kontrollimiseks. Maksustamine puudutas vaid neid mõisaid, mis olid ühel või teisel moel sattunud riigi kätte.

\footnotetext{
8 Holger Wichman, "Landskapshandlingarna i Kammararkivet”, Meddelanden från Svenska Riksarkivet för åren 1978-1979 (Stockholm, 1982), 89.

9 Riksarkivets beståndsöversikt. Del 4. Kammararkivet, utg. av Christer Danielson i samarbete med Helmut Backhaus, Jan Brunius och Lars-Olof Skoglund, Skrifter utgivna av Riksarkivet, 8 (Stockholm, 1995), 31, 76-77.

10 Sveriges traktater med främmande magter IV: 1561-1571, utg. O. S. Rydberg (Stockholm, 1888), 329-349.
} 
Rootsi võimu alla langenud ala halduse korraldamine ja maksusüsteemi sisseviimine toimus kestvate sõdade tõttu aeglaselt. ${ }^{11}$ Rootsi valdused Eestimaal hõlmasid alasid, mille pindala oli 1560. aastate alguses kasvav, kuid pärast 1567. aastat juba kahanev. Mida oli seal administreerida? Riigi kätte läksid lagunenud orduriigi kroonumõisad ja suur hulk sõja tulemusel omanikuta jäänud eramõisaid. Neid oli võimalik aja jooksul uutele omanikele läänistada, kuid vahepealsel ajal maksustas neid riik. Makse nõudsid sisse rootsi või soome päritolu foogtid, kes koostasid oma aruanded rootsi keeles. ${ }^{12}$ Rootsi haldusele oli tüüpiline, et esimene maksustamine toimus kohe pärast seda, kui maa oli läinud riigi valdusesse. Nii hakati vaatamata segastele sõja-aja oludele ka Harju-, Viru- ja Järvamaal peaaegu kohe pärast 1561. aastat Rootsi riigile makse nõudma. ${ }^{13}$

Eesti alal oli valitsenud süsteem, mille kohaselt olid külad ja väljaspool külasid paiknenud hajatalud organiseeritud omalaadi maksustusüksusteks - vakusteks. Riigi uute maksude jaoks, mis pidid tulema kroonumõisatest, koostati vakuraamatud, mis sarnanesid Rootsi ja Soome foogtiarvetega. Tüüpilise vakuraamatu sisuks oli erilaadsete koormiste määrad, näiteks kümnis (tavaliselt teraviljas), ja kindlaksmääratud maksud (tavaliselt fetalier), aga ka talupoegade päevatöö kohustus. Loeteludes olid talupojad pandud kirja talude kaupa ja need nimekirjad sisaldasid mitmesuguseid huvitavaid andmeid, näiteks märkusi talunike päritolu, küla ametimeeste, uusasunike (nn üksjalad) ja vabadike kohta. Arvukalt on vakuraamatuid säilinud Hiiumaalt, Tallinna ümbrusest ja Järvamaa keskosast. Ülejäänud piirkonnad on Rootsi Kammerarhiivi ulatusliku materjali hulgas tunduvalt vähem esindatud, kuna Harju-, Järva-, Viru- ja Läänemaal puudus suurte alade üle korralik kontroll ja seetõttu ei olnud seal võimalik vakuraamatuid koostada. ${ }^{14}$

\footnotetext{
${ }_{11}$ Sõdade ajastu algas Vene-Liivi sõjaga 1558. a ning lõppes Rootsi ja Venemaa vahel 1617. a sõlmitud Stolbovo rahuga ning Rootsi-Poola vahel 1629. a sõlmitud Altmarki vaherahuga. Nendes sõdades võitlesid üksteisega Rootsi, Poola ja Venemaa, alguses ka Taani, kuid viimane tõmbus tegelikult tagasi juba 1570. a, suutes jätta enda kätte Saaremaa.

12 Eesti ajalugu III: Rootsi ja Poola aeg, peatoim Hans Kruus (Tartu: Eesti Kirjanduse Selts, 1940), 110-112. Rootsi ametnike kohta Eestimaal vt Werner von Schulmann, Die zivile Staatsbeamtenschaft in Estland zur schwedischen Zeit (1561-1710), Abhandlungen des Instituts für Heimatforschung an der livländischen Gemeinnützigen und Ökonomischen Sozietät zu Dorpat, 6 (Dorpat \& Posen, 1939), 10-16, 29-49, 61-62, 71-140, 154-155, 158-159. 13 Enn Tarvel, “Orduaeg, 1227-1581", Järvamaa, I: Loodus, aeg, inimene (Tallinn: Eesti Entsüklopeediakirjastus, 2007), 331.

14 Kari Tarkiainen, "De baltiska vackeböckerna från 150o-talet som befolknings- och agrarhistoriska källor", Arkiv hemma och ute, Årsbok för Riksarkivet och Landsarkiven 1995 (Stockholm, 1995), 76-86.
} 
Seda, kui palju hiljuti riigiga ühendatud provintsidest 1560. aastatel makse saadi, on keeruline hinnata. Pideva sõja hävitustööd on elavalt kirjeldanud kaasaegsed kroonikud Balthasar Russow ja Johann Renner, kelle sõnul valitses kõikjal viletsus. Kuid samal ajal õnnestus efektiivsel Rootsi maksusüsteemil - vähemalt alguses, enne kui 1570. aastal puhkes sõda Venemaaga provintsist tähelepanuväärses ulatuses makse koguda. Ka kirjutas Russow, et kui Vene armee võttis 1571. aastal Harjumaalt ja Järvamaalt taganedes kaasa tuhandeid kariloomi, mitmeid tuhandeid teraviljaga täidetud regesid ning lisaks põletas ja rüüstas maa, teatasid nii aadlikud kui ka talupojad seepeale, "et nad sellest kahjust ei hoolivat, kui ainult hullemat ei tule". ${ }^{15}$

Seda, et kohe pärast Rootsi võimu kehtestamist püüti saada ülevaadet kogu Eestimaast ja selle maksustamisvõimalustest, näitab Ajalooarhiivis säilitatav Eesti alade maa- ja maksuraamat 1564.-65. aastast. ${ }^{16}$ See allikmaterjal - täpsema nimega Räntan och mantalet utav alla Kungl. Maj:t till Sverige, vår allernådigste herres slott och gårdar uti Livland - ei ole tekkinud revisjoni läbiviimise teel, vaid kujutab endast mingis ametiasutuses arve- või vakuraamatutest tehtud kokkuvõtet. ${ }^{17}$ Maa- ja maksuraamatu koostamise eesmärgiks oli vajadus saada ettekujutus Rootsi valdusesse läinud endiste ordu-, piiskopi-, kloostri- ja nn kadutseeritud mõisate ja külade majandusliku kandevõime ning potentsiaalsete sissetulekute kohta. Maa- ja maksuraamat on võrreldes vakuraamatutega palju ülevaatlikum, hõlmates ulatuslikuma ala. Ilmnevad suured kohalikud erinevused talurahva maksusüsteemis, mille riigivõim jättis puutumata, sest sellised muutused oleks sõjaaja oludes tekitanud vaid segadust ja võinuks kaasa tuua riigi sissetulekute vähenemise.

Eestimaal muutis omandisuhteid märgatavalt Rootsi kuningate läänistamispoliitika. Kui esialgu kuulus märkimisväärne osa haritavast maast kroonule, siis olukord muutus kiiresti seoses maade läänistamisega Erik XIV ja Johan III poolt. Mõlemad kuningad soovisid viia Eestimaal läbi õigusreformi ja luua samasuguse õigusastmete süsteemi nagu Rootsis. Need katsed põrkasid aga kohalike vastupanule ning rüütelkond säilitas oma talupoegade suhtes kaelakohtuõiguse (hals- och handrätt). Mainitud kuningate ajal katsetati siiski pidevalt ala tugevamat integreerimist Rootsiga. ${ }^{18}$

15 Balthasar Russow, Liivimaa kroonika, alamsaksa keelest tõlkinud Dagmar Stock, Hermann Stock, järelsõna Hermann Stock (Tallinn: Hotger, 1993), 204-205.

16 Ajalooarhiiv [edaspidi EAA], f. 1, n. 2, s. 930.

17 Herbert Ligi, Eesti talurahva olukord ja klassivõitlus Liivi sõja algul (1558-1561) (Tallinn: Eesti NSV TA Ajaloo Instituut, 1961), 14-15, viide 27.

18 Berndt Federley, Konung, ståthållare och korporationer: studier i Estlands förvaltning 1581-160o, Societas Scientiarum Fennica; Commentationes Humanarum Litterarum, 
1580. aastate lõpus prooviti muuta Eestimaa olukorraga sobimatut, foogtkondadel põhinevat majandushalduse süsteemi. 1561. aastast alates rajatud väikesed foogtkonnad, mille keskuseks oli linnus või mõni muu kindlustatud punkt, olid pindalalt tunduvalt kahanenud. 1587. aastal Tallinna asehalduriks saanud Gustav Banér rajas 1589. aastal Tallinna maksukambri (räntekammare). Selle ametnikeks olid üks rentmeister (räntmästare) ja neli väljaõpetatud kirjutajat (kammarskrivare), kes kirjutasid puhtaks kohalikke arveid ja saatsid need kontrollimiseks alguses Soome maksukambrisse (räntekammare) Turus, hiljem Stockholmi arvekotta (kammaren). See katse luua Eestimaal ühtne majandushaldus kukkus läbi juba 1590. aastal, kui Banér kaotas oma positsiooni asehaldurina. ${ }^{19}$ Seejärel saatsid foogtid oma arved taas otse Stockholmi.

\section{Rootsi esimene revisjon Eestimaal 1586-1590}

Lisaks jooksvale maksustamisele korraldas Rootsi kroon oma võimu algperioodil Eestimaal suure maaomandi ülevaatuse ehk revisjoni. Korralduse Eestimaal revisjon läbi viia andis kuningas Johan III juba 12. juulil 1581 , kuid selle teostamine tõusis päevakorda alles 1585 . aastal. ${ }^{20}$ Revisjon oli oluliseks sammuks Eestimaa haldamise ja maksustamise korraldamisel. Selles revisjonis ilmneb esimest korda Rootsi faktiline võim Harju-, Viru-, Järva- ja Läänemaa üle, mis moodustasid nüüd poliitilise terviku. Revisjonidel on vakuraamatute jt sarnaste dokumentidega võrreldes suured eelised: need on koostatud ühtsetel alustel ja haaravad ühel ajal suuri alasid. Ühtsed läbiviimise printsiibid ja meetodid ning teadete kontrollimine tõstavad materjali usaldusväärsust ja teevad eri revisjonide andmed omavahel kergesti võrreldavaks.

Eestimaal oli revisjoni eesmärgiks teha kindlaks aadli ja üldse läänimeeste maaomanduse suurus ja selle õiguslik alus. Lisaks olid revisjonil ka halduslikud ning fiskaalsed eesmärgid. Peeti vajalikuks koguda teateid talupoegade arvu, nende maksualuse maa pindala ning koormiste laadi ja suuruse kohta nii maavalduste kaupa kui ka kokkuvõtlikult suuremate alade kohta.

1586. aastal määras Johan III Eestimaa mõisate valitsemise küsimuses ametisse kuningliku kontrollkomisjoni. Komisjoni liikmeteks olid

30:1 (Helsingfors, 1962), 29-43.

19 Federley, Konung, ståthållare och korporationer, 21-23.

20 Paul von Ungern-Sternberg, Die Revision vom Jahre 1586 und die Befragung vom Jahre 1586: ein Beitrag zur Gütergeschichte Estlands, Beiträge zur Kunde Est-, Liv- und Kurlands, VIII (Reval: Franz Kluge, 1915), 2. 
kõrgaadli seast pärit Klaes Åkesson Tott, Klaes Bielke, Kristian Gabrielsson Oxenstierna, Ture Bielke ja Karl Henriksson Horn ning sekretäriks alamaadli hulgast pärit Henrik Mattsson Huggut, kel oli kameralistliku haldamise kogemusi. ${ }^{21}$ (Seesama aadlike rühm oli 1585. aastal sõlminud Venemaaga Pljussa jõe suudmes vaherahu. ${ }^{22}$ ) Kuninglikul komisjonil oli volitus teha otsuseid kiiresti ja vahetult kuninga nimel ning sel moel kohalikest ametnikest mööda minna.

Kuninglik komisjon alustas tööd 25. jaanuaril 1586 Virumaal Jõhvis, kus algas läänimeeste valdusõiguste kontroll, kusjuures poliitilisele momendile alguses tähelepanu ei pööratud. Revisjoni teostamiseks pidid volinikud käima läbi kogu Eestimaa. Kuna ülesanne oli keeruline, jäi töö venima ja võttis rohkem aega, kui oli planeeritud. Üheks põhjuseks oli ka see, et kolm aastat hiljem, täpsemalt 1589. aastal lisati revisjonile küsitlus, mida kuningas Johan III oma otsusega veel 12. augustil 1590 täiendas, ning alles siis oli võimalik revisjon lõpule viia. Revisjoni tulemusel valminud maaraamatud on dateeritud 1591. aastaga. ${ }^{23}$

Komisjoni töö tekitas aadlikest mõisaomanikes suurt rahutust. Seda põhjustas eelkõige poliitiline kontroll aadli sõjaaegse lojaalsuse üle Rootsi suhtes. Need, kes olid avalikult valinud Poola või Venemaa poole, pidid algse plaani kohaselt kaotama oma mõisad, kuid ebalojaalsetena käsitleti ka neid, kes olid olnud neutraalsed. Selliseid mõisnikke oli arvukalt ja neile lisandusid ka juba surnud aadlike lesed ja lapsed. Et vältida täielikku laostumist, pakkusid sellises seisus olevad aadlikud vabatahtlikult ühte neljandikku oma valdustest Rootsi kroonile, et nad saaksid pidada enda käes ülejäänud osa. Pärast teatud kõhklusi otsustas Johan III siiski, et oma mõisad säilitavad kõik, kes ei olnud võidelnud Rootsi riigi vastu. Esimese neljandikreduktsiooni (fjärdepartsreduktion) risk läks sel moel Eestimaa aadlist mööda. ${ }^{24}$

1586. aasta revisjon oli seega eelkõige valdustiitlite revisjon. Tehti vahet kroonumõisate ja aadlimõisate vahel, kusjuures viimati mainitute puhul

\footnotetext{
21 Almquist, Den civila lokalförvaltningen i Sverige, II, 558.

22 Jakob Koit, "Om de estländska kamerala kopieböckerna från 160o-talets första hälft i svenska samlingar. Beskrivna i deras godspolitiska sammanhang", Meddelanden från Svenska Riksarkivet för åren 1978-1979 (Stockholm, 1982), 105.

23 Rootsi esimese maarevisjoni allikaid - revisjoniprotokoll 1586. aastast, läänikirjad ja maade register 1583-99 ja revisjoni maaraamatuid 1599. aastast (kokku 8 köidet) säilitatakse Rootsi Riigiarhiivis [edaspidi RA] sarjas Östersjöprovinsernas jordrevisionshandlingar, vol. 1-8, vt Riksarkivets beståndsöversikt. Del 4. Kammararkivet, 379. 24 Werner Tawaststjerna, Pohjoismaiden viisikolmattavuotinen sota, I: Vuosien 1570 ja 1590 välinen aika, Historiallisia tutkimuksia, I (Helsinki: Suom. Kirj. Seuran Kirjapaino, 1918-1920), 703-704; Loit, Kampen om feodalräntan, 51.
} 
eristati päritud mõisaid (arffegods) ja läänistatud mõisaid (förlähnte gods). ${ }^{25}$ Valdajal või tema õigusjärglastel tuli esitada oma õigusi tõendavad dokumendid (läänikirjad, ostu-müügilepingud jms). Revisjoni tulemusel valminud register sisaldaski andmeid eramõisate omanike ja nende maaomandi õigusliku aluse kohta, viimane oli saadud eri tüüpi valdustõenditest (åtkomsthandlingar). Põhjalikud teated on kirja pandud maaomaniku päritolu ja ta sugulaste, eelkõige poegade kohta. Ostetud maavalduse puhul pandi kirja ostusumma. Lisaks tehti revisjoni märge ka omaniku sõjaaegse truuduse kohta kuningale ja ratsateenistuse (rusttjänst) kohustuse suurus.

Revisjoni läbiviimisel pöörati suurt tähelepanu talupoegade kohustustele maaomanike suhtes. Nimelistelt on üles märgitud viimastele kuulunud külad, kõrtsid ja veskid ning kokkuvõtlikult ka nende adramaade ja talude arv. Lisaks määrati kindlaks maavalduse paiknemine ja ulatus ning märgiti tühjade talude ning üksjalgade ja vabadike arv. Lahus paiknenud külade puhul on esitatud täpsed andmed nende asukoha kohta. Revisjoniga seoses koostatud maaraamatusse on kirja pandud kõik talupojad külade kaupa. ${ }^{26}$

Revisjoni originaalprotokoll ei ole säilinud, kuid Paul von UngernSternberg on selle rekonstrueerinud Rootsi Riigiarhiivis säilitatava üheksa käsikirja alusel. Seejuures on ta kasutanud ka hilisemast ajast (1595-1600) pärit materjale. Töö tulemus avaldati 1915. aastal. ${ }^{27}$

Register on Eesti ala agraar- ja asustusajaloo jaoks oluline allikas, sest see annab esimese tervikliku ülevaate Eestimaa hertsogkonnast ning esitab võrdluseks andmeid ka aastast 1561, mil Eestimaa läks Rootsi võimu alla. Läbiviidud maade registreerimine jäi suures osas kehtima rohkem kui sajaks aastaks. ${ }^{28}$ Eestimaa 1586.-90. aasta revisjon lõi aluse, millele rajati hiljem kogu provintsi haldus- ja maksusüsteem.

\section{Maarevisjon Eesti- ja Liivimaal 1600.-1601. aastal}

On teada, et ka kuningas Sigismund kavatses Eestimaal üldise maarevisjoni läbi viia, kuid mõttest ta kaugemale ei jõudnud - et mitte maal

\footnotetext{
25 Almquist, Den civila lokalförvaltningen, 556-557.

26 RA, Östersjöprovinsernas jordrevisionhandlingar, vol. 5, 6. Herbert Ligi on maininud ka 1591. aasta revisjoni, mille dateerimisel on aluseks Lihula linnuselääni vakuraamatusse hilisemal ajal tehtud märkus (EAA, f. 1, s. 2, n. 32, 1. 82), vt Ligi, Eesti talurahva olukord ja klassivõitlus, 20, viide 33. On alust arvata, et tegemist on siiski 1586.-90. aastate revisjoniga, mille teostamine venis 1591. aastani.

27 Ungern-Sternberg, Revision vom Jahre 1586.

28 Almquist, Den civila lokalförvaltningen, 558-559.
} 
valitsevas ebakindlas olukorras aadlit veelgi enam ärritada. ${ }^{29}$ Revisjoni otsustas teostada hertsog Karl, kes oli majandanud oma hertsogkonda (Södermanland, Närke ja Värmland) Gustav Vasa vaimus. Ta pidas vajalikuks kõrgeid makse ja süvenes väiksematessegi detailidesse. ${ }^{30} 1600$. aastal püüdis hertsog Karl sekkuda siinsetesse agraaroludesse, kehtestades adramaal põhineva ühtse maksumäära. See samm ei jõudnud siiski olukorda kuigivõrd mõjutada, kuna nälja- ja katkuajad tegid igasuguse ratsionaalse planeerimise võimatuks. ${ }^{31}$

Et saada maalt sissetulekuid, oli vaja seda maad tunda. Esimene Rootsi revisjon Eestimaal näis hertsog Karlile ebarahuldava ja puudulikuna ning lisaks olid andmed nii mõisate kui ka talupoegade osas vananenud. Vaja oli saada ülevaade ka üldisemate majanduslike ja ühiskondlike olude kohta, sest riik oli nii sularahapuudusel kui ka poliitilistel põhjustel sunnitud andma tasuks teenete eest palga asemel lääne. Ka sõjakoormiste määramiseks oli vaja täpseid andmeid niihästi lääni- kui ka riigimaadel elavate talupoegade arvu ja maksuvõime kohta. Armee vajas sõdureid, mistõttu oli Karl juba Eestimaa rüütelkonnale antud privileegides 3. septembril 16oo. aastal visandanud süsteemi, mille kohaselt pidid mõisaomanikud and ma sõjaväele iga 15 adramaa kohta ühe täielikult varustatud ratsaniku. Nii see siiski ei läinud, sest talupojad ei saanud relva kanda ja kroon sai teatud kompensatsiooni sel moel, et rüütelkond pidas ülal üht aadli lipkonda (adelsfana).

Paides 5. detsembril 1600 välja antud avaliku volitusega käskis hertsog Karl Eestimaal läbi viia üldise revisjoni. ${ }^{32}$ Volituses, mis oli ühtlasi ka instruktsiooniks, põhjendati revisjoni läbiviimise vajadust väitega, et kuigi talupojad tasusid koormisi, nagu jaksasid, jõudis sellest riigikassasse vähem, kui pidanuks. Revisjoni üheks eesmärgiks oli seega talupoegade kandevõime ja maksukohustuse täitmise kindlakstegemine. Volikirjas ei olnud juttu maavaldusõiguste kontrollist, vaid igas piirkonnas oli vaja kindlaks teha riigile kuuluvate ja läänistatud maade suurus. Selle alusel sai hinnata riigi võimalikke sissetulekuid. Selle volituse toel pidi inspektor käima lossist lossi, mõisast mõisa ja küsima igalt talupojalt eraldi, kui palju ta tasub kümnist ja teisi makse nii põllu- kui ka alemaalt, kusjuures kõik koormiste liigid oli vaja eraldi kirja panna. Võrdluseks pidi ta hankima infot kümnise

\footnotetext{
29 Jakob Koit, "Om de estländska kamerala kopieböckerna”, 106.

30 Lennart Hedberg, Företagarfursten och framväxten av den starka staten: Hertig Karls resursexploatering i Närke 1581-1602, Örebro studies, 11 (Örebro, 1995), 332-333.

31 Almquist, Den civila lokalförvaltningen, 555.

32 Korhonen, "Rootsi revisjon Baltimail", 6.
} 
maksmise kohta ka foogtidelt. Lisaks oli vaja välja selgitada söötis adramaad. ${ }^{33}$ Kõik andmed tuli esitada hertsogi kantseleisse.

Seega oli ette kirjutatud revisjoni läbiviimise meetod, milleks oli küsitlemine. Instruktsioon puudutas küll Eestimaad, kuid hiljem kohandati seda ka Liivimaale, mille kohta ei olnud üldse andmeid. Riik vajas infot mõisate adramaade arvu kohta, kuid hertsog Karli rahulolematus aadliga oli põhjuseks, miks ei loodud aadlikest koosnevat komisjoni. Kuivõrd revisjoniga ei kaasnenud aadli valdusõiguste kontrolli, siis saadeti 2. mail 1601 hertsogi nimel Tallinna kantseleist maakondadesse välja kuues eksemplaris mandaat, mis käskis aadlikel ilmuda linna, et ette näidata oma Brieffe und Siegell. See tähendas aadli valdusõiguste kontrolli algust, mille eesmärgiks oli võtta riigile tagasi ebaseaduslikult hõivatud maad. ${ }^{34}$

Eestimaal viidi revisjon läbi kolme kuu jooksul 1600. aasta detsembrist kuni 1601 . aasta märtsini. ${ }^{35}$ Seejuures tugineti enamasti varasematele andmetele, mis Rakvere ja Narva osas olid küll vaid umbkaudsed. ${ }^{36}$ Neist ilmnesid nii läänide suurus, lääniõiguslikud omandivormid kui ka riigi sissetulekud. Kasutamist leidsid eelkõige 1599. aasta majandusaruanded, kuid lisaks tehti ka järelepärimisi ja muudeti nende alusel varasemaid teateid. ${ }^{37}$

1601. aasta märtsis jõudsid Rootsi väed Väina jõeni. Kuna rootslaste sõjaline edu oli suur, osutus revisjon Liivimaal veelgi vajalikumaks kui Eestimaal. Liivimaa ei olnud kunagi kuulunud Rootsile, mistõttu olid siinne valitsemis- ja maksusüsteem tundmatud. Võib arvata, et vallutatud aladele lihtsalt laiendati Eestimaa revisjoni, ent eesmärgid olid sealjuures veidi teistsugused. Kui Eestimaa puhul oli esikohal fiskaalne pool, maksustamise korrastamine ja ühtlustamine, siis Liivimaal oli selleks vallutatud maast ülevaate saamine. Informatsiooni polnud ei läänistatud maade suuruse ega ka maksustamise üldpõhimõtete kohta. Ka Liivimaal kasutati ära varasemaid andmeid, konkreetsemalt varasemate Poola-aegsete revisjonide materjale.

Liivimaa revisjoni läbiviimise meetodi kohta on olemas ainult kaudseid teateid. Arvi Korhonen on välja selgitanud, et revisjoni viis läbi Michel Jordan. ${ }^{38}$ Revisjon algas Viljandis 17. märtsil 1601, sealt läks revident

33 Korhonen, "Rootsi revisjon Baltimail", 6-7.

34 Koit, "Om de estländska kamerala kopieböckerna ”, 107.

35 Korhonen, "Rootsi revisjon Baltimail", 6-7, 21.

36 Vt Th. Schiemann, Der älteste schwedische Kataster Liv-und Estlands: eine Ergänzung $z u$ den baltischen Güterchroniken (Reval: Franz Kluge, 1882).

37 Korhonen, "Rootsi revisjon Baltimail", 19.

38 Korhonen, "Michel Jordan", 97-118. Ta oli sündinud Pommeris, kolis 1580. aastatel Viljandisse Poolale kuulunud Liivimaal ja tõusis seal bürgermeistriks. Seoses hertsog 
Tarvastusse, kus revisjon toimus 20. märtsil. ${ }^{39}$ Edasi Karksisse, kus revisjon toimus 27. märtsil, ja sealt Pärnusse, kus revideerimise kuupäevaks oli 6. aprill. Pärast seda suundus revident lõunasse ja vaatas ajavahemikus 10. aprillist kuni 18. juunini üle Läti alad põhja pool Väinat. Pärast Ruhjat on revident üles märkinud umbkaudsed andmed Härgmäe ja Helme aladelt. Helmes olevat lossipealik Wilhelm Todwen teda töös takistanud ja ka Karksi alal keeldus Oder Todwen oma pärismõisa kohta teateid andmast, mis viitab maaomanike omavahelisele kokkuleppele suhtuda revisjoni vaenulikult. ${ }^{40}$ Tõenäoliselt oli plaanis hiljem revisjoni täiendada, aga poolakate võidukas pealetung ajas selle kavatsuse nurja.

Suvel oli revideerimistöös pikk seisak ja alles 24. augustil algas revisjon Liivimaa idaosas Tartumaal. Esmalt revideeriti Kirumpää, Vaabina ja Antsla. 15. septembril jõuti Kastresse, 21. septembril Räpinasse. Rõngu, Rannu, Otepää ja Tähtvere revideeriti ajavahemikul 1. oktoobrist 7. oktoobrini. Lõpuks siirdus revident Laiuse piirkonda, kus ta oli 12. oktoobril, ja sealt Põltsamaale, kus ülevaatuse päevaks on märgitud 16. oktoober. ${ }^{41}$ Kõikides linnuseläänides ja mõisates ei ole revisjoni päeva märgitud ja mitmel pool (Lugaži, Härgmäe ja Helme) jäidki revisjoni andmed väga napiks ja pealiskaudseks. ${ }^{42}$ Revisjoni läbiviimisel oli Jordanil kaasas neli abilist: saksakeelne ja rootsikeelne sekretär ja kaks teenijat, kes oskasid kohalikke keeli. ${ }^{43}$

Külad on revisjoniprotokollis kirja pandud linnuseläänide kaupa ja vakusteks jagatuna. Loetletud on kõik taluperemehed ja talu adramaade arv, kusjuures sageli on kirja pandud ka kasutatud adramaa liik (enamasti saksa või poola adramaa). ${ }^{44}$ Iga küla kohta on esitatud kokkuvõtlik talude ja adramaade arv. Kirja on pandud nii veskid, kõrtsid ja veekogud kui ka tühjenenud külad. Eraldi on välja toodud üksjalad (enamasti uusasunikud) ja vabadikud. Hulgaliselt on märkusi erandlike olukordade kohta - talupoja vaesumine või pagemine, koormiste tasumine rahas või kalades, poolemeeste nähtus, aga

\footnotetext{
Karli sissetungiga läks ta üle Rootsi poolele ja sai kameriiri ameti arvekojas.

39 Vt Oleg Roslavlevi poolt koostatud kaarti EAA, f. 5392, n. 1, s. 98.

40 Schiemann, Der älteste schwedische Kataster, 94; Korhonen, "Rootsi revisjon Baltimail", 14 .

${ }^{41}$ Korhonen, "Rootsi revisjon Baltimail", 15.

42 Švābe, Die älteste schwedische Landrevision Livlands, 337-382.

43 Korhonen, "Michel Jordan", 102.

44 Saksa adramaa ehk taluadramaa keskmine normaalsuurus oli 1o ha. Poola adramaa võrdus nelja saksa adramaaga. Adramaade kohta vt täpsemalt Enn Tarvel, Adramaa: Eesti talurahva maakasutuse ja maksustuse alused 13.-19. sajandil (Tallinn: Eesti Raamat, 1972), 66-76; Enn Tarvel, Adratalupoegade olukorrast Lõuna-Eestis XVI sajandi lõpul ja XVII sajandi algul (Tallinn: Eesti NSV TA Ajaloo Instituut, 1964), 12-13.
} 
ka talupoja kurtmine, et tema maa tegelik suurus ei ole vastavuses adramaa arvuga, koos viidetega varasematele Poola-aegsetele revisjonidele. Kubjaste puhul oli protokollis märge nende maksuvabastuse kohta. Iga vakuse lõpus oli loetelu läänimeestest, kusjuures enamasti on nimeliselt kirja pandud ka nendele läänistatud külad koos adramaade arvuga. Linnuselääni kohta esitati talupoegade koormiste suurus ühelt saksa adramaalt.

Revisjoni koostamise meetodi väljaselgitamiseks annab võtme asjaolu, et teadete korjamiseks jäi reisimise kõrval väga vähe aega ja kõiki talupoegi polnud võimalik küsitleda. Revisjoni alusmaterjaliks oli seega kindlasti mingi suusõnaline või kirjalik andmestik ning revisjon piirdus selle kontrollimise ja täiendamisega, eriti lääne puudutavate teadete osas. Probleemiks oli revisjoni teostaja madal seisus, mistõttu lossihärrad ja mõisaomanikud keeldusid mõnikord koostööst ja teated jäid ebatäpseteks. ${ }^{45}$

1601. aasta revisjoni läbiviimisel tehtud algseid ülestähendusi ei ole säilinud. Ilmselt olid need kirjutatud üksikutele lehtedele ja nende põhjal koostati hilisemad kokkuvõtted, milles esialgseid ülestähendusi on kasutatud erisuguse täpsusega. Ka summeerimine sooritati nähtavasti alles revisjoniraamatute kokkuseadmisel, kusjuures piirkondi on laiemateks administratiivüksusteks ühendatud eri viisil, millega on seletatavad ka mitmed eksimused. ${ }^{46}$

Kui 1638. aastal selgus, et Jordan ei olnud revisjoniraamatut arvekotta toimetanud, nõudis Soome kindralkuberner Per Brahe tema poja käest selle veel samal aastal välja ning laskis sellest teha kammerkolleegiumi jaoks kokkuvõtte. Paksu, 359 foolioleheküljega köidet pealkirjaga "1601. aasta Liivimaa revisjon" säilitatakse Rootsi Kammerarhiivis. Köite alguses on 70-leheküljeline saksakeelne koopia Poola-aegsest revisjonist Tartumaal, mille viis 1588. aastal läbi Woyczech Wnuk ${ }^{47}$ Kokkukogutud läänikirjade andmed kirjutas teine Rootsi kameriir Nils Jönsson Krämer mahukasse koopiaraamatusse. ${ }^{48}$

\footnotetext{
45 Korhonen, "Rootsi revisjon Baltimail”, 17, 21.

46 Ibid., 17.

47 Arvi Korhoneni arvates pärines see revisjon 1581. aastast, A. Svābe järgi oli see koostatud pärast 1590. aastat. Hans Kruus esitab Poola revisjoni läbiviimise ajaks 1588. a, vt Hans Kruus, "Arveds Švabe. Die älteste schwedische Landrevision Livlands. Latvijas Universitātes Raksti. Tautsaimniecības un tiesību zinātnu fakultātes serija II. 3. Latvijas Universitāte. Riga 1933", Ajalooline Ajakiri, 1 (1934), 48. Hans Kruusi seisukoha õigsust kinnitab ka avaldatud revisjonimaterjal: Polnische Akten, I: 1582-1591, Hefte zur Landeskunde Estlands, 5, hrsg. von Oleg Roslavlev (München, 1970), 293.

48 Selle maarevisjoni materjal paikneb Rootsi Kammerarhiivi kogus, RA, Östersjöprovinsernas jordrevisionshandlingar, vol. 9. Vt ka Riksarkivets beståndsöversikt. Del 4. Kammararkivet, 379 .
} 
1882. aastal avaldas Theodor Schiemann 1601. aasta revisjonist kokkuvõtliku kompilatsiooni, mis oli koostatud käsiraamatuks kameralistidele Eesti- ja Liivimaal. ${ }^{49}$ Tema poolt esitatud teated selle revisjoni kohta on suures osas ebaõiged või puudulikud. ${ }^{50}$ Käsiraamatus on iga ala kohta nimetatud esmalt selle varasem omanik ja revisjoni läbiviimise päev, mille all on arvatavasti mõeldud revisjoni lõpetamise päeva. Sellele järgnevad vakuste ja külade kaupa talupoegade nimed ja nende adramaade arv, samuti küla adramaade, tühjade adramaade, perede, üksjalgade, veskite jt maksustusüksuste summa. Seejärel on kirjas läänid ja aadlimõisad, kuid nende talupoegi ei loetleta nimeliselt. Iga ala lõpus on kokkuvõtlik maksuselgitus (Gerechtigkeit), mis loetleb, kui palju ja mis liiki maksu igast maksuüksusest tasutakse; siis kiriku maaomand ja maksud ning lõpuks terve maa-ala maksuüksuste kogusumma (summa summarum).

1601. aasta revisjon ei kujunenud täielikuks, sest see viidi läbi sõjaaja tingimustes ja olukorras, kus kohalikud ametimehed ei uskunud Rootsi võimu püsimajäämisesse ning andsid seetõttu teateid vastumeelselt. Liivimaa ja osa Eestimaa taasvallutamine Poola poolt võttis revisjonilt ka praktilise tähtsuse.

Puudustele vaatamata on 1601. aasta revisjon väärtuslikuks allikaks Liivimaa rahvastiku oludest rahuajal - enamik kogutud andmeid jääb aega enne laastavat Rootsi sõjaretke ja nälga, mistõttu hilisemad allikad näitavad juba hoopis teistsuguseid olusid. Ilmneb, et maa oli pärast Vene-Poola sõjaga seotud tühjenemist hästi taastunud. Andmed annavad ettekujutuse asustuse üldisest laadist, mitmel pool võime näha suuri külasid. ${ }^{51}$ Kirja on pandud ka piirkonna veskid. Talupoegade nimekirjad annavad aimu talupoegade lisanimedest ja ka võõraid on allikas esile tõstetud. Eraldi on välja toodud vabatalupojad, nende hulgas kupjad, üksjalad ja vabadikud. Loend annab ülevaate läänimeestest ja nende maavaldustest. Paraku on 1601. aasta revisjoni andmeid suhteliselt keeruline hilisematega võrrelda, sest andmed läänistatud alade kohta on kohati ebapiisavad - sageli on mainitud ainult läänistatud talude ja adramaade üldarv. Lisaks toimusid nälja ja katku tõttu asustuses olulised muutused.

On teada, et kümmekond aastat hiljem, 1612. aasta jaanipäeva eel saadeti Jordan Stockholmist uuesti Eestimaale mõisaid revideerima ja valdusõigusi kontrollima. Seekord ei tulnud käsk mitte kuninga, vaid kammernõuniku

\footnotetext{
49 Schiemann, Der älteste schwedische Kataster.

50 Korhonen, "Rootsi revisjon Baltimail", 2.

51 Vt Ülle Liitoja, Põhja-Tartumaa talud 1582-1858, I-IV (Tallinn: Eesti Ajalooarhiiv, 1992).
} 
käest. Jordani põhjalik töö võttis poolteist aastat aega ja mitmel pool olid selle tulemuseks uued vakuraamatud. Jordanil oli kaasas rootsi- ja saksakeelne sekretär ning kaks teenijat, kellest üks oskas eesti keelt. Maal reisimine oli seotud suurte raskustega - nii toidumoon kui ka voodiriided pidid endal kaasas olema, mis annab tunnistust kohalike ebasõbralikust suhtumisest. Viletsate teede tõttu suri hobuseid. Revideerimise aruandeid viimistleti Tallinna arvekojas, kus Jordan pidi tasuma nii kütte kui ka valgustuse eest. ${ }^{52}$ Töö tulemuseks oli koopiaraamat, mida säilitatakse Rootsi Riigiarhiivis. ${ }^{53}$ Kuningas Gustav II Adolf pidas Michel Jordani tehtut siiski ebapiisavaks ja andis uue ülesande kameriir Nils Jönsson Krämerile. Tema tegevust on peetud uue revisjoni ettevalmistamise eeltööks. ${ }^{54}$

Pärast rahulepingu sõlmimist Venemaaga 1617. aastal Stolbovos oli Rootsi riigi juhtkonnal aega mõelda uute revisjonide peale Eestimaal, kuna 1601. aasta revisjonist oli möödunud juba palju aega. Vastav komisjon nimetati 14. augustil 1619 ja selle koosseisu kuulusid liikmetena Jacob De la Gardie, Adam Schrapfer, Fromhold von Tiesenhausen ja Evert Bremen ning sekretäridena Conrad Schliesser ja Nils Jönsson. ${ }^{55}$ Komisjonile anti samal päeval Kalmaris volikiri ja 14-punktine instruktsioon. ${ }^{56}$ Eesmärgiks oli läbi viia üldine revisjon (generalrevision) Eestimaal. Kuningas oli rahulolematu, et nii palju mõisaid oli läinud erakätesse, mistõttu ei saanud riik uuel sõjaajal garnisonide ülalpidamiseks piisavalt sissetulekuid. Kavas oli aadli valdusõiguste kontroll, kusjuures need, kes kasutasid mõisaid ilma vastavate õigusteta, pidid oma valdused kaotama. Üheks plaaniks oli mõisad sissetulekute saamiseks aadlikele rentida. Inspiratsiooni oli saadud ilmselt hiljuti vallutatud Ingerimaalt, kus suured riigi maavaldused olid rendile antud majanduslikult aktiivsetele suuraadlikele nagu Bogislaus Rosen, Henrik Fleming ja Jakob De la Gardie. Eestimaal jäi revisjon suure hulga valdustõendite ja läänikirjade läbivaatamise ja kopeerimise juures siiski peatuma. Ilmselt oli selle ainuke kameraalne tulemus 1620. aasta Eestimaa maaraamat. Maaraamat on hiljem avaldatud kokkuvõtlikul kujul, kuid seda ei saa siiski vaadelda kui revisjoniakti või -toimikut. ${ }^{57}$

\footnotetext{
52 Korhonen, "Michel Jordan", 105.

53 RA, Östersjöprovinsernas jordrevisionshandlingar, vol. 10.

54 Koit, "Om de estländska kamerala kopieböckerna", 109-110.

55 Ibid., 113.

56 RA, Riksregistraturet, 14.8.1619.

57 Vt Almquist, Den civila lokalförvaltningen i Sverige, III, 250-279; Koit, "Om de estländska kamerala kopieböckerna”, 117 .
} 
1617.-1619. aasta revisjon Liivimaal

1617. aastal vallutas Rootsi Poolalt kaks Liivimaa loodeosa linnuselääni Riia lahe rannikul paiknenud Pärnumaa ja selle lõunapoolel asuva Salatsi piirkonna. ${ }^{58} 1617$. aasta revisjon oligi nende vallutustega seotud ja kestis koos vaheaegadega kuni 1619. aastani. Selle revisjoni eesmärk erines 1601. aasta omast. Kui sajandi algul tehti esimesi samme Liivimaa allutamisel Rootsi riigile ja tegeleti olukorra väljaselgitamisega, siis 1617.-19. aastal oli eesmärgiks valdusõiguste kontroll ja mõisamajanduse korraldamine.

Revisjoni läbiviijateks määrati sõjakomissarid (volinikud) Adam Schrapfer ja Nils Stiernsköld; Schrapferi abiliseks määrati kirjutaja Andres Schwartz. 18. septembril 1617 anti neile ulatuslik instruktsioon, mis on sellest revisjonist ka ainus säilinud allikmaterjal..$^{59}$

Instruktsioonis rõhutatakse vallutatud aladel korra tagamise vajadust. Revisjoni ülesandeks oli välja selgitada ala püsivad asukad - nii aadlikud, kodanlased kui ka talupojad. Aadlike puhul tuli nõuda, et nad esitaksid oma läänikirjad kas originaalide või tõendatud koopiatena. Eriti oluliseks peeti maa kandevõime väljaselgitamist, selleks tuli koostada nii vallutatud alade riigimõisate, aadlike kui ka kodanlaste varade täielik inventarinimekiri. See võimaldas saada ettekujutust, kui suuri makse suudaksid nad tasuda.

Vastavalt instruktsioonile oli suur osa sõjakomissaride ülesannetest seotud ametnike ametissepanekuga. Nende puhul oli vaja hinnata sobivust, võtta truudusevanne ning hoolitseda palga maksmise eest. Lisaks pidid komissarid korraldama ka sõjaväe ülalpidamist ning ala kaitsmist vaenlaste eest, kusjuures eriliselt rõhutati vajadust kaitsta talupoegi, et nad saaks põldu harida ja koormisi kanda. Schrapferi ja Schwartzi ülesandeks oli arveraamatute pidamine, kusjuures selle töö eest nähti neile ette prii ülalpidamine.

Erilist tähelepanu pöörati selles dokumendis maksustamisele. Komissarid pidid üles loetlema kõik Pärnu ja Salatsi maavaldused ning seejuures ei pidanud nad nende maksustamisel lootma ainult maaomanike sõnadele, vaid uurima ka mõisakupja ja talupoegade käest, millised on talupoegade senised kohustused olnud. ${ }^{60}$ Suurt tähelepanu pöörati sõjaväega seotud küsimustele, mis näitab, et revisjoni korraldamise eesmärgiks oli Rootsi

58 Axel Norberg, Polen i svensk politik 1617-26, Acta Universitatis Stockholmiensis, 19 (Stockholm: Almqvist \& Wiksell, 1974), 47-50.

59 Kommissionen till organisering av administrationen i Pernaus och Salis områden 1617, RA, Livonica II:562; vt ka Ragnar Liljedahl, Svensk förvaltning i Livland 1617-1634 (Uppsala: Almqvist \& Wiksell, 1933), 30-31; Dunsdorfs, Vidzemes arklu revizzijas, 249-252. 60 RA, Livonica II:562. 
sõjategevuse toetamine. Kuna komisjonil oli vaja palju ringi liikuda, pidi Schrapferi käsutuses olema kümme abilist ja kuus hobust, Schwartzil aga kolm abilist ja kaks hobust.

Korralikult revisjoni siiski läbi viia ei õnnestunud, sest Poola vallutas ala tagasi ning Rootsile jäi vaid Pärnu linn ja selle ümbrus. Selles piirkonnas tegutses ilmselt Schrapfer veel 1619. aasta alguses, lastes lahti kõlbmatuid mõisavalitsejaid ja määrates nende asemele uusi. Revisjoni kohta on märge ka 1638. aasta revisjoniprotokollis, mis näitab, et revideerimine leidis tõepoolest aset. ${ }^{61} \mathrm{Nii} 1601$. aasta kui ka 1617.-19. aasta revisjon toimusid sõja ajal ning kuna maa vallutamine ei jäänud püsima, ei näidanud neis esitatud andmed enam hiljem maal valitsevat tegelikku olukorda.

Aastatel 1617-19 pooleli jäänud Liivimaa revisjoni kulg on tähtis seetõttu, et samasugust mudelit kasutati ka hiljem. Esmalt võeti Rootsi uutelt alamatelt truudusvanne. Seejärel algas maavaldusõiguste kontroll, mille käigus vaadati üle kõik varasemad läänikirjad ja privileegid. Ajal, mil ülevaatus või kontroll kestis, oli maaomand kroonu valitsemise all. Ametisse pandi kuninglikke foogte, hinnati mõisatest saadavat sissetulekut ja tulud suunati garnisonide ning sõjaväe ülalpidamiseks. ${ }^{62}$

\section{Gustav II Adolfi revisjon Liivimaal 1624.-1627. aastal}

Järgnevalt pöördus Rootsi võimude tähelepanu Eestimaale, kus plaaniti 1626.-27. aastal viia läbi järgmine üldrevisjon. Ametisse nimetati kuninglik komisjon, mille liikmeteks olid Philip Scheiding, Per Sparre ja Henrik Fleming. Aset pidi leidma ka kirikuvisitatsioon, mille läbiviijaks määrati Västeråsi piiskop Johannes Rudbeckius. Aadli maapäevaga tekkis siiski kokkupõrge, mistõttu Rootsi riik ei suutnud oma plaane teostada ning sellega kadus aadli jaoks ka revisjoni oht. ${ }^{63}$ Luhtus lootus kohandada Eestimaa olusid nii ilmalikes kui ka kiriklikes asjades rohkem Rootsi nõuetele vastavaks, mis oleks viinud Eestimaa tihedama integreerimiseni. Sellega seoses varises kokku ka lootus kasutada samu meetodeid hiljem Liivimaal. See oli selge tagasilöök Rootsi püüdlustele Läänemere maades. ${ }^{64}$

${ }^{61}$ Dunsdorfs, Actus Revisionis Livoniae, XIV; Liljedahl, Svensk förvaltning i Livland, 17.

62 Liljedahl, Svensk förvaltning i Livland, 31.

63 RA, Livonica II:621, Martin Aschanaeus' kopiebok.

64 Vt Liljedahl, Svensk förvaltning i Livland, 194-197; Aleksander Loit, "Reformation und Konfessionalisierung in den ländlichen Gebiete der baltischen Lande von ca. 1500 bis zum Ende der schwedischen Herrschaft", Die baltischen Lande im Zeitalter der Reformation und Konfessionalisierung, hrsg. von Matthias Asche, Werner Buchholz und Anton Schindling, Katholisches Leben und Kirchenreform im Zeitalter der Glaubens- 
1621. aastal algas uuesti sõda ning Rootsi okupeeris kogu Liivimaa kuni Väinani, kaasa arvatud Riia ja Tartu (1625). See Liivimaa osa, mille Rootsi 1621.-25. aastal üle võttis, oli olnud ligi nelikümmend aastat Poola võimu all. ${ }^{65}$ Maa oli jagatud kolmeks presidentkonnaks (Võnnu, Tartu, Pärnu) ja need omakorda staarostkondadeks. Poola rajatud alus oli ainus, millele Rootsi haldus sai Liivimaal tugineda. ${ }^{66}$ Piirkonnal ei olnud sel ajal rüütelkonda, mis oleks võinud olla kokkulepete tegemisel vastaspool, pealegi oli suur osa aadlikest põgenenud.

Püüded vallutatud maal olusid korrastada algasid kohe pärast Riia kapituleerumist 15. septembril 1621. Tähelepanuväärne on, et Riia linna ja piirkonna kuberneriks nimetati Jesper Mattsson Kruus, kes oli olnud Stockholmis riigi rahameistri (riksskattmästaren) kõrges ametis. Sellise kogemustepagasiga mehe määramisest kuberneriks ilmneb maksuasjade prioriteet Rootsi plaanides. Maavalduste omanikud pidid viivitamatult esitama valdustõendid, mille alusel nad oma mõisaid kasutasid. Teatati, et need aadlikud, kes olid varem olnud Rootsi poolel ja kaotanud oma valduse, võisid selle tagasi saada. Omandisuhted olid siiski väga segased. Läänistamisasjades oli otsustusõigus kuningal, kelle tegevus oli suunatud Poola aja suurte kroonumõisate võtmisele Rootsi krooni alla ja nende läänistamisele Rootsi ülikutele. ${ }^{67}$ Praktikas kaalus juriidilisi asjaolusid ka Riia komisjonikohus (kommissionsrätt), kes selgitas välja eri läänistuste õigusliku põhjendatuse.

Nii nagu mujal, oli ka siin reformitöö nurgakiviks omandiõiguslike ja maksustuslike olude väljaselgitamine. Seetõttu muutus ulatuslik revisjon möödapääsmatuks. Selle revisjoni korraldamisel oli kolm tähtsamat eesmärki. Esiteks oli vaja kontrollida mõisaid, mis olid riigiametnike kontrolli all. Teiseks oli vaja korraldada kuninga poolt kõikidele talupoegadele

spaltung, 69 (Münster: Aschendorff, 2009), 100-101; Koit, “Om de estländska kamerala kopieböckerna", 119-120 jt.

65 Enn Tarvel, "Livlands statsrättsliga ställning före uppgången i svenska väldet 1625", Stat - kyrka - samhälle: den stormaktstida samhällsordningen i Sverige och Östersjöprovinserna, utg. Torkel Jansson \& Torbjön Eng, Acta Universitatis Stockholmiensis; Studia Baltica Stockholmiensia, 21 (Stockholm: Almqvist \& Wiksell, 2000), 305-329.

66 Tartu 1625. a kapitulatsioonilepingus määrati, et kõik Poola dokumendid, mis olid Tartu linnuses, tuli loovutada Rootsile (RA, Militaria 1290. Krigshistoriska handlingar IX:2. Gustav II Adolfs polska krig i Livland 1619-1629, Jacob De la Gardie kiri 16. augustist 1625). Ulatuslik ladinakeelne Poola revisjon on säilinud Rootsi Riigiarhiivis: Livonica II: 47, 48.

67 Liljedahl, Svensk förvaltning i Livland, 37-45. 
kehtestatud uue korralise maksu - statsiooni - sisseseadmist. Kolmandaks pidi revisjon kaasa aitama vallutatud ala sõjalise kaitse organiseerimisele ${ }^{68}$

Revisjoni läbiviimiseks nimetati 1622. aastal komisjon, kuhu kuulusid Adam Schrapfer, Henrik Rehbinder, Engelbrekt von Tisenhusen ja Magnus Nieroth. Revisjoni instruktsioon 16. juulist 1622 nägi ette, et vaja on loetleda kõik talupojad ja üksjalad ning panna kirja nende lapsed ja sulased, loomade arv ning koormiste suurus. ${ }^{69}$ Märgiti üles ka see, kui kaua oli talupoeg kohapeal olnud, tehes vahet pärustalupoegadel ja võõrastel. Suurt tähelepanu tuli pöörata tühjenenud taludele, kusjuures oli vaja välja selgitada, kellele tühjenenud ala kuulus. Andmeid oli vaja koguda eelkõige kubjaste ja rehepappide käest, uurides neilt teateid nii veskite, kõrtside, kalastusvõimaluste ja käsitöö kui ka kiriklike olude ja patronaadiõiguse kohta. Kuninga poolt tulnud uuendus puudutas andmete kogumist ka eravalduste talupoegade kohta, sest ka nemad pidid hakkama statsiooni maksma. ${ }^{70}$

Revisjoni ettevalmistusi tehti ilmselt juba 1623. aastal, kuid enamik protokolle pärineb 1624. ja 1625. aastast. Revisjon algas Pärnus 9. märtsil 1624 ning 12. märtsiks jõuti lõpule kogu Pärnu lossi piirkonna revideerimisega. Protokollile on kirjutanud alla neljast ülalmainitud aadlimehest kolm, Adam Schrapferi asemel osales revideerimises Heinrich von Ungern ja kirjutajaks oli Johannes Elert. Karksi lossiläänis viidi revisjon läbi 9. septembril ja Põltsamaa lossiläänis 10. detsembril 1624. ${ }^{71}$ Viljandi, Helme ja Tarvastu kohta revisjoni läbiviimise aeg puudub. Kuna suurem osa tööst tehti 1624. aastal, on seda Pärnu kreisi osas nimetatud 1624. aasta revisjoniks. ${ }^{72}$ Seesama komisjon revideeris veel 17. detsembril 1624 ka Laiuse lossilääni. Revisjon viidi läbi eri aegadel, kuid mitme piirkonna lõplikule revisjoniprotokollile (Karksi, Helme, Laiuse) kirjutati alla ühel ajal - 5. märtsil 1625, mis tähendas revisjoni lõpuleviimist Pärnu kreisis ja Laiuse lossiläänis.

1624. aasta revisjon viidi läbi tunduvalt põhjalikumalt kui eelmised revisjonid ja selle käigus kirjapandud informatsioon on märgatavalt mitmekülgsem. Läänistatud mõisate puhul esitati andmed maaomaniku kohta ja anti ülevaade ka mõisahoonete, loomade arvu ja põldude suuruse kohta. Talupojad pandi kirja kas vakuste või läänistatud alal mõisate kaupa, kusjuures enamasti märgiti, millist adramaad (enamasti poola või saksa adramaa) sel alal on kasutatud. Esmalt on revisjonis antud talude ja adramaade

\footnotetext{
68 Dunsdorfs, Vidzemes arklu revizijas, 278.

69 Ibid., 252-254.

70 Dunsdorfs, Actus Revisionis Livoniae, XIV-XV.

71 Revisjoni käigu kohta vt Oleg Roslavlevi koostatud kaarti EAA, f. 5392, n. 1, s. 99.

72 Vt Heinrich Laakmann, Das "Revisionsbuch wegen dess Hauses Pernow" Anno 1624 (Pernau, 1914).
} 
arv terve küla kohta, kusjuures sageli on viited ka sellele, kui palju talusid ja adramaid on külas vanasti olnud, enamikul juhtudel on selle all mõeldud aega enne Liivi sõda. ${ }^{73}$

Talud pandi kirja peremehe nimega ja lisaks adramaade arvule pöörati tähelepanu ka talupoja päritolule, pere koosseisule, loomadele (hobused ja lehmad) ning koormiste määrale ja suutlikkusele seda täita. Mõisa kohta selgitati välja summaarne adramaade arv, mille järgi arvestati statsioon ja ratsaväeteenistuskohustus. ${ }^{74}$ Statsiooni maksmisest olid vabastatud vabatalupojad, uusasukad ja vabadikud.

Revisjoni läbiviimine edenes vastavalt maa vallutamisele. 1625. aastal läks Rootsi võimu alla ka Tartu ümbrus ning revisjon viidi Tartumaal läbi 1627. ja 1628. aastal. Komisjoni kuulusid Roetger von Tiesenhausen (Thisenhaussen), Hinrich von Rosen ja Fridericus Regnis. Von Rosen suri revisjoni läbiviimise ajal. ${ }^{75}$ Emajõest lõuna poole jäänud Ahja, Mäksa, Kastre, Räpina ja Vastseliina mõisas toimus revisjon 1627. aasta oktoobris. Novembris revideeriti Kirepi, Rõuge ja mitmed teised mõisad ning detsembri alguses Antsla. Tartust põhja pool algas revisjon 8. detsembril ja seal revideeriti Äksi ja Maarja-Magdaleena kihelkonna mõisaid ning Raadi mõis. Kursisse jõuti järgmise aasta 1. jaanuaril ja sealt suunduti Tähtvere kaudu Otepääle ja Põlva piirkonda. Tartu revideeriti 5. jaanuaril. Puhja kätte jõudis järg 28. jaanuaril ja sealt reisis komisjon 31. jaanuaril Rannusse. Rõngu revideerimine toimus 5. veebruaril, kuid sellega ei olnud töö veel läbi, sest Kuigatsi mõis revideeriti alles 4. septembril 1628. aastal. Rootslased vallutasid ka Liivimaa lõunaosa 1625. aastal ning seal viidi revisjon läbi 1627. aastal. Revidendid külastasid isiklikult Alulinna ja Koiva piirkonda, kuid Gulbene osas tuli tugineda põgenike andmetele. ${ }^{76}$

Tartumaal teostati revideerimine tunduvalt põhjalikumalt kui varem Pärnumaal ja Laiuse lossiläänis. Siin oli revisjoni tegemisel abiks ulatuslik Poola võimu ajast pärinev kameraalne materjal, nii maaraamatud kui ka revisjonid. Erinevalt Pärnumaast esitati Tartumaal revisjoni andmed enamasti ülevaatlikult tabelite kujul, kusjuures tabelis olid lahtrid nii taluperemehe poegade, tütarde kui ka sulaste arvu jaoks. Loomadel oli talu kandevõime üle otsustamisel suur tähtsus, seetõttu on lisaks hobustele ja lehmadele kirja pandud ka härgade, lammaste ja sigade arv. Kohati on esitatud vägagi põhjalikud andmed külvi ja koormiste kohta.

\footnotetext{
Ligi, Eesti talurahva olukord ja klassivõitlus, 21.

Dunsdorfs, Actus Revisionis Livoniae, XV.

Das Dorpater Land 1624/27, 166.

76 Dunsdorfs, Vidzemes arklu revīzijas, 279.
} 
Ülevaate saamist vallutatud ala kohta peeti väga oluliseks ala kohese maksustamise eesmärgil. Selle nimel töötasid lisaks revidentidele ka mitmed Rootsi ametimehed. Töö algas juba enne revisjoni läbiviimist ja isegi veel enne, kui piirkond oli Rootsi kätte langenud. Teha täielik nimekiri kogu piirkonna mõisatest oli vägagi keeruline ülesanne, nagu ilmneb ka Tartu lääni asehaldur Nils Stiernskiöldi paljudest kirjadest arvekojale. See instants oli nimelt nõudnud "tõelist maaraamatut kogu lääni kohta, mis on täielik, näitab asustatud ja asustamata adramaad ja kui suurt osa talupoeg tegelikult kasutab" ${ }^{77}$ Stiernskiöld rõhutas, et maa oli suur, 70 miili pikk ja 30 miili lai ning haaras seitset lossi ja 80 mõisat, mistõttu ei olnud võimalik oodata väga kiireid tulemusi. ${ }^{78}$

Lisaks asehaldurile tegutsesid Liivimaal kaks hiljuti aadeldatud rootslast Måns Mårtensson Palm ja Erik Andersson Trana. Mõlemad olid olnud sõjakomissarid ja tegelenud armee ülalpidamisküsimustega sõdades Venemaa ja Poolaga. Palm tegutses Liivimaa lääneosas (Pärnu piirkonnas ja Koknese ümbruses) juba umbes 1617. aasta vallutuste alal, Trana Liivimaa idaosas (Tartu piirkonnas), mis oli vallutatud hiljem. Nad mõlemad said eri instruktsioonid, kusjuures Tranat manitseti kohaliku aadli suhtes suuremale ettevaatlikkusele. Kõik aadlikud said juhul, kui nad olid jäänud paigale, säilitada oma valdused vastavalt 1625 . aasta instruktsioonile. ${ }^{79}$ Sõjakomissarid pidid koostama jooksvalt maaraamatuid ja korraldama maksustamist.

Erik Andersson Trana tegevusest maa kiire maksustamise korraldamisel on palju jälgi kirjavahetuses kuninga, riigikantsleri ja arvekojaga. Lisaks Liivimaale täitis ta samalaadseid ülesandeid ka Ingerimaal. Kohe pärast Tartu kapituleerumist 18. augustil 1625 võis Erik Andersson kirjutada, et ta oli teinud 1624. aasta maksude alusel summaarse maaraamatu kogu piirkonna kohta. Jooksva aasta olukord oli siiski väga ebaselge ja maksud olid talupoegade käest täiesti kogumata. Kuigi Liivimaa oli "oivaline (härligt) maa", oli siinne majanduslik olukord väga kaootiline ja murettekitav ${ }^{80}$ Hästi tehtud töö tulemusena usaldas kuningas Erik Anderssoni kätte Tartu piirkonna kogu majandusliku juhtimise.

Mõni aeg hiljem teatas komissar, et talupojad olid hulgaliselt koos oma loomadega üle Vene piiri pagenud, kuid venelastega käivat nende tagasisaamise üle läbirääkimised. Seetõttu jäid nii lõikus kui ka sügiskülv suures

77 RA, Kammarkollegiets arkiv E II a:16. Kammarkollegiets kansli, ankomna brev, kiri 12. septembrist 1626

78 Ibid.

79 Liljedahl, Svensk förvaltning i Livland, 46-51.

80 RA, Skrivelser till konungen. Gustav II Adolfs tid 9, Erik Andersson Trana kiri kuningale 18. augustil 1625 . 
osas maakonnast tegemata. Olukorda raskendas pärandiks saadud Poolaaegne vilets mõisate valitsemine - poolakad olid ainult joonud ja tantsinud, kirjutas Erik Andersson. ${ }^{81}$ Juba 4. novembril suutis usin komissar saata Stockholmi esimese nimekirja talupoegade ja võimalike maksude kohta. Ta märkis kaaskirjas, et tema arvutused põhinesid talupoegade endi öeldud adramaade arvul, mis olid seetõttu tõenäoliselt liiga madalad. Talupojad olevat olnud nii hirmunud, et nad põgenenud üle piiri, kui vaid nende peale vihase pilguga vaadati. ${ }^{82}$ Järgmisel aastal olid komissari mured seotud Tartu lähedale Rootsi sõjaväekoloonia rajamisega, mille tarvis ta oli loetlenud piirkonnas 129 adramaad ja 401 maksustatud talupoega. ${ }^{83}$

Vallutatud alade maksustamise korraldamine ja maaraamatu koostamine võttis umbes kaks aastat. Üks hilisem samalt sõjakomissarilt kuningale saadetud kiri sisaldas andmeid, mille kohaselt hakkas töö jõudma lõpule, kuigi selle tegija oli liiga suure töökoormuse all peaaegu kokku kukkumas. ${ }^{84}$ Lõpptulemusena saadeti idapoolse Liivimaa maaraamat ja maksustamisplaan 6. juulil 1627. aastal Stockholmi. ${ }^{85}$

Måns Mårtensson Palm tegutses samalaadsete ülesannetega Liivimaa lääneosas. Tema abiline Johann Mayer reisis ringi Salatsi lossiläänis, et koostada piirkonna mõisate kohta inventar. Komissar ise tegutses Kokneses, et loetleda mõisaid, talupoegi ja nende koormisi. ${ }^{86}$ Probleemiks oli kompetentsete rootsi või saksa rahvusest kirjutajate puudus. 1625. a augustis saatis Palm Koknesest kuningale teate, et ümbruskonna lossiläänide talupoegade maksustamise kava on valmis. Komissar oli vastu talupoegade kasutamisele lõikuse ajal Koknese ja Riia ehitus- ja kindlustamistöödel. ${ }^{87}$ Seega tegutsesid sõjakomissarid samades piirkondades ja revisjoni läbiviimisega samal ajal, kuid nende ülesanded olid veidi teistsugused ja suunatud eelkõige maa vahetule haldamisele ja maksustamisele.

${ }_{81}$ RA, Skrivelser till konungen. Gustav II Adolfs tid 9, Erik Andersson Trana kiri kuningale 9. oktoobril 1625; vt ka Arvi Korhonen, Eerikki Antinpoika (Porvoo: Werner Söderström Osakeyhtiö, 1953), 137-139; Ragnar Liljedahl, Svensk förvaltning i Livland, 43-53.

82 RA, Skrivelser till konungen. Gustav II Adolfs tid 9, Erik Andersson Trana kiri kuningale 4. novembril 1625

83 RA, Oxenstiernska samlingen. Brev till rikskanslern Axel Oxenstierna, vol. E 741, Erik Andersson Trana kiri riigikantsler Axel Oxenstiernale 29. aprillil 1626.

${ }_{84}$ RA, Skrivelser till konungen. Gustav II Adolfs tid 9, Erik Andersson Trana kiri kuningale 7. juunil 1627 .

85 Ibid., Erik Andersson Trana kiri kuningale 6. juulil 1627.

86 RA, Oxenstiernska samlingen. Brev till rikskanslern Axel Oxenstierna, vol. E 681, Måns Mårtensson Palmi kiri Axel Oxenstiernale 30. juulil 1625.

${ }_{87}$ RA, Skrivelser till konungen. Gustav II Adolfs tid 9, Måns Mårtensson Palmi kiri kuningale 7 . augustil 1625 . 
1623.-28. aastatel Liivimaal läbiviidud revisjon oli põhjalikum kui eelmised, kuid sõjaolukorra tõttu teostati see osade kaupa mitme aasta jooksul, mistõttu ei saadud maa olukorrast terviklikku pilti. Kuna terved piirkonnad olid alles hiljuti olnud sõja tallermaa, vananesid revidentide kogutud andmed olude muutumise tõttu kiiresti.

Revisjoni materjalide võrdlemine varasema, 1601. aasta revisjoni tulemustega paljastab Liivimaal toimunud demograafilise katastroofi ulatuse. 1601.-03. aastate katk ja näljaaeg tabasid Eesti- ja Liivimaad samal määral. Vastavalt ajavahemikus 1623-28 toimunud revisjonile koosnes Liivimaa Eesti osa kogu rahvastik 2780 talust, lisaks oli 369 vabadikukohta. Nii madal arv on uurijates kahtlusi tekitanud, sest selle järgi olid 1601. aastaga võrreldes tühjad umbes 75 protsenti taludest. ${ }^{88}$ Eriti palju oli kannatada saanud maa keskosa, kuid ka Viljandi ja Tartu ümbrus. Tunduvalt väiksemad olid kahjud Tartumaa kaguosas ja Helme lossiläänis oli tühjana vaid 31 protsenti adramaadest. ${ }^{89}$

Igat liiki maaomand muudeti sõltuvaks kuningas Gustav II Adolfi kinnitusest. Rootsi aristokraatia sai nii suuri läänistusi, et need võisid haarata terve endise staarostkonna tuhandete talupoegadega. Näiteks sai riigikantsler Axel Oxenstierna 1622. aasta augustis läänistuseks terve Võnnu piiskopkonna. Ka teised Rootsi kõrgaadlikud, nagu Jakob De la Gardie, Svante Banér, Gustav Horn, Nils Stiernsköld, Måns Mårtensson Palm, Johan Banér, Carl Carlsson Gyllenhielm, Per ja Axel Banér, Nils Brahe ja Herman Fleming, tasustati rikkalikult. Läänistamise tempo oli nii kiire, et 1630. aasta paiku oli kogu kroonu maaomand Liivimaal juba suurte läänistustena riigiaadlikele välja jagatud. Läänistused tehti reeglina 1604. aasta Norrköpingi otsuse alusel, mis tähendas meesliinis pärimise sisseseadmist. ${ }^{90}$ Eeltoodud põhjustel ei olnud edasiste reformiplaanide läbiviimisel palju abi aastatel 1623-28 toimunud revisjonist, mistõttu muutus uus revisjon peagi vältimatuks.

\section{0. aasta revisjon Liivimaal}

Pärast relvarahu sõlmimist määrati 1629. aastal Liivimaa, Ingerimaa ja Karjala kindralkuberneriks Johan Skytte. Tema ülesandeks oli kasvatada põllumajandusest saadavaid sissetulekuid ja integreerida nii Liivi- kui ka

\footnotetext{
88 Ülle Liitoja-Tarkiainen, Hajatalud ja külad Põhja-Liivimaal 17. sajandil (Tartu: Eesti Ajalooarhiiv, 200o), 64.

89 Liitoja-Tarkiainen, Hajatalud ja külad, 64-65.

90 Liljedahl, Svensk förvaltning i Livland, 43-44.
} 
Ingerimaa võimalikult täielikult Rootsi riiki. ${ }^{91}$ Riik oli huvitatud läänistamata alade maksutulude kasvatamisest. ${ }^{92}$

Liivimaal peeti vajalikuks korraldada kiiresti uus revisjon, sest varasemad eri aegadel läbi viidud osalised revisjonid ei vastanud enam tegelikule olukorrale. Pärast sõda oli toimunud ulatuslik maade taasasustamine ja talurahva jõukus oli vahetult sõjajärgse olukorraga võrreldes kasvanud. Adramaade osas valitses Liivimaal suur mitmekesisus, mistõttu revisjoni teiseks eesmärgiks oli eri liiki adramaade suuruse väljaselgitamine ja ühtlustamine.

Korralduse revisjoni läbiviimiseks andis kindralkuberner Johan Skytte. See revisjon erinebki ülejäänutest käesolevas artiklis vaatluse alla võetud revisjonidest selle poolest, et käsk selle korraldamiseks ei tulnud kuningalt. Lisaks maarevisjonile viidi Johan Skytte juhtimisel 1632. aastal läbi ka valdusõiguste revisjon.

Instruktsioon revisjoni läbiviimiseks on alla kirjutatud 22. mail 1630. aastal..$^{93}$ Vastavalt sellele oli vaja selgitada välja, kellele kuulusid läänistused ja kui suur oli nende adramaade arv. Vanemate talupoegade käest oli vaja küsida, kelle ülesandeks oli kirikute ülalpidamine ja kellele kuulus patronaadiõigus. Talupoegade puhul tuli kirja panna, kas tegu oli pärustalupoja või võõraga, ja viimasel juhul kindlaks teha, kui kaua ta oli kohapeal elanud. Väljaselgitamist vajas adramaade arv, kusjuures erilist tähelepanu tuli pöörata sellele, milliste adramaadega oli tegemist (poola või saksa adramaa). Koormiste puhul taheti teada nii jalapäevade kui ka rakendiga tehtud päevade arvu ja ka seda, kui palju oli talupoeg 1628.-29. aastal statsiooni maksnud. Kirja oli vaja panna ka tühjad talud ja see, kelle maa peal nad asusid. Välja tuli selgitada vabadike ja käsitööliste maakasutus ja perede struktuur. Kui enamasti pidid revidendid esitama küsimused otse talupoegadele, siis koormiste, eriti teokohustuse asjus oli vaja pöörduda kupja poole, kuid lisaks tuli temalt saadud teateid veel kontrollida. Informatsiooni oli vaja koguda ka mõisa kohta, pöörates tähelepanu hoonetele ja põldudele, aga ka kalapüügivõimalustele ja veskitele, ning teha kindlaks, millised olid mõisarentniku sissetulekud.

Revisjoni läbiviimiseks loodi mitu komisjoni, kusjuures Liivimaa põhjaosaga oli seotud neist kaks. ${ }^{94}$ Godhard Welling, Magnus Wolfelt ja Nico-

${ }_{91}$ Erland Sellberg, "Skytte, Johan”, Svenskt Biografiskt Lexikon, 32 (Stockholm, 20032006), 502-513.

92 Jerker Rosén, "Statsledning och provinspolitik under Sveriges stormaktstid: en författningshistorisk skiss", Scandia, 17:2 (1936), 267.

93 Dunsdorfs, Vidzemes arklu revīzijas, 254-258.

$94 \quad$ Ibid., 43, 254-258. 
laus Langenberg teostasid 1630. aasta septembris revisjoni mitmes Läti ala piirkonnas ja ka Karksi, Viljandi, Tarvastu ja Helme linnuseläänis. ${ }^{95}$ Teise osa Eesti ala revisjonist viisid 1630. aasta sügisel vastavalt kindralkuberner Johan Skytte instruktsioonile läbi Valentin Trost ja Bartholtz Nyberus. ${ }^{96}$ Kogutud andmed on enam-vähem sarnased eelmise, 1624.-28. aastal toimunud revisjoniga. Osalt on kogutud materjal esitatud tabelitena, kuid suurem osa on siiski kirja pandud pikema jooksva tekstina.

1630. aasta revisjon oli esimene, mis teostati rahu tingimustes ja hõlmas tervet Liivimaad. Täpsuselt ja andmete rohkuselt ületas see kõik eelmised revisjonid. Kahjuks on selle revisjoni materjalid säilinud vaid osaliselt. ${ }^{97}$

Ka 1630. aasta revisjoni tulemused ei suutnud Rootsi halduse nõudeid rahuldada. Rahu tingimustes muutus olukord asustuse taastumise ja ulatusliku sisserände tõttu kiiresti. ${ }^{98}$ Revisjoni andmed ei peegeldanud juba paar aastat pärast selle läbiviimist maa tegelikku majanduslikku seisu. Kõige suuremaks puuduseks oli, et revisjoni tähtsaimat eesmärki - adramaade ühtlustamist - ei suudetud korralikult täita. ${ }^{99} \mathrm{Ka}$ oli revisjonis märgatud palju vigu, mis puudutasid ratsateenistuse ja talupoegadelt kogutud statsiooni suurust. Kuigi revisjoniga pandi kirja ka talupoegade kohustused mõisa ees, ei olnud makse arvestatud iga talu kohta eraldi, vaid mõisa kohta kokkuvõtlikult, sest statsioon koguti ja maksti enamasti mõisa kaudu. Riigi jaoks oli probleemiks see, et kuigi talupojad olid muutunud jõukamaks ja mõis sai suuremat tulu, maksti statsiooni endisel moel, mistõttu mõis lõikas sellest kasu ja loovutas kroonule liiga väikese osa. ${ }^{100}$ Samas kurtsid mõisad statsiooni liiga kõrge taseme üle.

Kammerkolleegium vajas täpseid ja selgeid revisjoniraamatuid. 1635. aasta veebruaris nõudis kammerkolleegium Riia kuberner Anders Erikssonilt (Hästehufvud), et revisjoniraamatud saadetaks Rootsi. Anders Eriksson vastas 20. mail, et see on võimatu, sest Skytte poolt teostatud revisjoni materjali säilitati Tartus ning Riias oli sellest olemas ainult kokkuvõte. Anders Eriksson püüdis asja küll korraldada, kuid ilmnes, et materjale oli võimatu saata, sest nad olid igapäevases kasutuses vajalikud. Anders Eriksson arvas, et nendest materjalidest oleks Rootsis vähe kasu, sest 1630. aasta revisjoni ei teostatud ühtse malli alusel ja seetõttu on sellest raske selgust

95 Latvijas Valsts Vēstures Archīvs [edaspidi LVVA], 7348. f., 1. apr., 6. 1.

96 LVVA, 7349. f., 2. apr., 28. 1.

97 Liivimaa kokkuvõtlik maaraamat ja läänistusregister on avaldatud: Almquist, Den civila lokalförvaltningen $i$ Sverige 1523-1630, III, 315-333.

98 Liitoja-Tarkiainen, Hajatalud ja külad Põhja-Liivimaal, 67.

99 Kiri 26. septembrist 1630, LVVA, 7400. f., 1. apr., 2. 1.; Tarvel, Adramaa, 104-106.

100 Dunsdorfs, Vidzemes arklu revīzijas, 280. 
saada. Adramaad on seal märgitud üles vastavalt talupoegade ütlustele, aga kuna eri poolel kasutati eri tüüpi adramaid, siis valitseb selles osas suur segadus ning piirialadel ei ole nende adramaade arvu üldse märgitud. Tema arvates oli vaja läbi viia uus revisjon, mille puhul oleks adramaid ühtlustatud ja saadud kammerkolleegiumi jaoks uued andmed. ${ }^{101}$

Kammerkolleegium ei olnud kuberneri vastusega rahul ja pärast uut nõuet saatis kindralkuberner Bengt Oxenstierna Stockholmi 1630. aasta revisjoni kokkuvõtte. Kammerkolleegium pidas seda ebatäielikuks ja liiga lühikeseks. Raamatupidaja Harald Bengtsson pidi selle ümber töötama nii, et välja oleks arvestatud iga linnuselääni riigimaksud. Kammerkolleegiumil oli nimelt kahtlus, et kroon saab tulusid vähem, kui tal õigus oli. ${ }^{102}$ Kindralkuberner oli seisukohal, et revisjoni materjalide ümbertöötamine on võimatu ja uus revisjon vältimatu, kuid kammerkolleegiumist ta sellele arvamusele vastukaja ei saanud. 14. veebruaril 1636 kirjutas kindralkuberner kuninganna Kristiina eestkostevalitsusele, et ta plaanib järgmiseks aastaks (1637) üldist revisjoni, et teha kindlaks adramaade arv ja määrata riigile makstavate maksude suurus. Selle jaoks tahtis kindralkuberner eestkostevalitsuselt volitust saada. Olude kiire muutumine ja revisjoni puudused tegid uue revisjoni läbiviimise vältimatuks.

Kammerkolleegium jätkas oma nõudmistega ja soovis 1637. aasta 23. märtsi kirjas maaraamatut, kus oleks olnud selgelt välja toodud ka tühjad maad, nii nagu Rootsis kombeks. Bengt Oxenstierna ja Anders Eriksson toonitasid jätkuvalt uue revisjoni korraldamise vajadust. Nende arvates oli vaid sel moel võimalik kindlaks teha õige adramaade arv ja määrata statsiooni suurus. Samal ajal oli vaja läbi viia ka valdusõiguste revisjon, sest eelmine, 1632. aastal koostatud oli ebatäielik. Uus revisjon oli nende arvates kasulik nii lääniomanikele kui ka riigile. ${ }^{103}$

\section{8. aasta Liivimaa revisjon}

Uue revisjoni suure pooldaja kindralkuberner Bengt Oxenstierna pingutused kandsid vilja. Lõpuks õnnestus tal uue revisjoni vajalikkuses veenda nii kohalikke võime kui ka keskvalitsust. Alguses kavatseti läbi viia üldine maarevisjon, mis haaraks ka Eesti- ja Ingerimaad, kuid tegelikkuses piirdus see vaid Liivimaaga. ${ }^{104} 1638$. aasta alguses saigi kindralkuberner kuninganna

\footnotetext{
101 Dunsdorfs, Actus Revisionis Livoniae, XVIII.

102 Ibid., XVIII-XIX.

103 Ibid., XIX-XX.

104 Liivimaa 1638. aasta maarevisjon, VIII.
} 
Kristiina eestkostevalitsuselt käsu viia kindralkubermangus läbi üldine maarevisjon. 10. jaanuaril 1638 allkirjastatud volituses põhjendatakse revisjoni korraldamise vajalikkust Liivimaal toimuvate suurte pettustega ratsaväeteenistuse ja statsiooni osas - nimelt olevat valesti üles antud või varjatud asustatud adramaid, mille alusel mõlemad koormised määratakse. ${ }^{105}$

Edgars Dunsdorfs on esile toonud neli põhjust, mis sundisid Rootsi riiki uut revisjoni korraldama. Nendeks olid: adramaade arvu kindlaksmääramine ja eri adramaa liikide ühtlustamine maa rahuaegse haldamise korraldamiseks; adramaade arvu tõstmine riigi sissetulekute suurendamiseks; lääniomanike valdusõiguste kontroll; vajadus kindlate ja selgete revisjoniraamatute järele. ${ }^{106}$

Bengt Oxenstierna alustas 1638. aasta suvel revisjoni ettevalmistavaid töid. Kogu ala haaravat komisjoni ei nimetatud, vaid ülesanded jagati mitme väiksema komisjoni vahel ja materjal pandi lõplikult kokku kindralkuberneri kantseleis. ${ }^{107}$ Kindralkuberner määras revisjoni läbi viima mitu peamiselt riigiametnikest koosnenud kohalikku komisjoni, mille ulatuslikud volikirjad on dateeritud augustikuu lõpuga. ${ }^{108}$ Erinevalt varasematest revisjonidest usaldati ülesanded täielikult sakslastest revidentidele. Igas komisjonis oli 3-4 liiget, kusjuures üks või kaks neist olid kohtunikud ja ülejäänud aadlikud või ametnikud.

Revisjon teostati sama aasta suve lõpul. Juba 24. juulil avaldas Bengt Oxenstierna käsu, milles kohustati kõiki läänistuste omanikke 23. augustil ja ka sellele järgnenud päevadel oma mõisas püsima, et võtta vastu komisjon, näidata neile läänikirja ning esitada sellest kaks õigeks tunnistatud koopiat. Lisaks pidid läänistuste hoidjad andma kõikidele kontrollijate küsimustele tõesed vastused. ${ }^{109}$

Revisjonikomisjonid varustati instruktsioonide ja nende juurde kuuluvate selgitustega ning käskkirjaga alustada revideerimist 23. augustil. Selgitus täpsustas mõningaid instruktsioonipunkte. Instruktsioonis ja selgituses ei määratud kindlaks komisjonide tööviisi ega kirjutatud ette ka ühtset vormi andmestiku fikseerimiseks. Ka komisjonid ise ei leppinud selles suhtes kokku. Nii kujunesid pea kõikide komisjonide protokollid

105 Dunsdorfs, Vidzemes arklu revīzijas, 258-259; Liivimaa 1638. aasta maarevisjon, VIII.

106 Vt Tarvel, Adramaa, 111.

107 Seda revisjonimaterjali säilitatakse Rootsi Kammerarhiivis: RA, Östersjöprovinsernas jordrevisionshandlingar, vol. 18-28; Riksarkivets beståndsöversikt. Del 4. Kammararkivet, 379.

108 Liivimaa 1638. a. maarevisjon, VIII-XI.

109 Ibid., VIII. 
erinevaks nii andmete täielikkuse kui ka ülestähendamisviisi poolest, mis raskendab nende võrdlemist. ${ }^{110}$

Põhimõtteline vahe eelmiste revisjonidega võrreldes oli see, et kindlaks määrati adramaa definitsioon. Üheks saksa adramaaks kästi lugeda niisugune talu, mille kandevõime, st kõlvikute suurus ja töötegijate arv, oli piisav, et kanda saksa adramaale tavalisi naturaalkoormisi ja teha aasta läbi terve nädala tegu ühe rakendiga. ${ }^{111}$ Revisjoni läbiviijad pidid koguma informatsiooni kubjastelt ja vanematelt talupoegadelt, kes sellel otstarbel vannutati.

Komisjonidele antud ülesanded olid laialdased, mida hästi näitab esimese, Tartumaal tegutsenud osakomitee instruktsioon. ${ }^{12}$ Komisjon pidi kindlaks tegema, millised olid selle ala mõisad, kes neid valitses ja milliste õigustega. Mõisa kohta oli vaja välja selgitada kalastusvõimalused ning veskid ja kõrtsid. Vanade talupoegade käest tuli uurida, millised on olnud talupoegade kohustused kirikute ülalpidamisel, kelle käes oli kiriku patronaadiõigus ning kas kirikuõpetaja koht oli täidetud. ${ }^{113}$ Välja oli vaja selgitada iga mõisa talude arv, kusjuures tähelepanu tuli pöörata ka sellele, millised neist olid asustatud ja millised tühjad. Adramaade arv pidi olema antud iga talu kohta eraldi. Oli vaja mainida, millisesse vakusesse talu kuulus. Iga taluperemehe puhul tuli märkida, kui kaua ta oli talus elanud, ja kirja panna ka perepojad. Talu kandevõime kindlakstegemiseks tuli välja selgitada nii veoloomade (härjad ja hobused) kui ka lehmade arv ning koormiste suurus. Üles tähendada tuli ka vabadikud. Revidendid pidid andma kubjastele teada, et ka nemad pidid makse maksma.

Instruktsiooni algusosa määratles üsna täpselt, mida komisjon arvesse võtma pidi. Sama instruktsiooni lõpuosa kirjutas aga ette, kuidas revidendid pidid ilmnenud puudustesse aktiivselt sekkuma. Nad ei pidanud neile esitatud adramaade arvuga nõus olema, vaid võisid seda ka oma tähelepanekute põhjal muuta, sest Liivimaal esines lisaks saksa adramaadele ka ordu ja Poola võimu ajast pärit suuri kohalikke adramaid ja nüüd oli vaja seda süsteemi ühtlustada. Mõisahärrad ja talupojad pidid omavahel maksude ja teokohustuse osas nii kokku leppima, et see oleks vastavuses saksa adramaadega. Ühe saksa adramaa suurune talu pidi sooritama veoloomadega põllutööd suvel nädala kõikidel päevadel, samal ajal kui väiksematelt adramaadelt nõuti vähem koormisi. Adramaade arvust sõltusid ka kroonile makstavad maksud, nagu statsioon ja ratsateenistuskohustus.

\footnotetext{
110 Liivimaa 1638. a. maarevisjon, XI.

111 Tarvel, Adramaa, 111.

112 LVVA, 7349. f., 2. apr., 28. 1, 148-150. lp.; Dunsdorfs, Vidzemes arklu revīzijas, 259-263.

113 Liivimaa 1638. a. maarevisjon, VIII-X; LVVA, 734. f., 2. apr., 28. 1, 148.-150. lp.
} 
Lõpuks pidid komisjoni liikmed puhtaks kirjutatud revisjoniprotokollile alla kirjutama ja selle kammerkolleegiumile saatma.

Revisjon viidi läbi 1638. aasta hilissuvel ja sügisel. ${ }^{114}$ Põhja-Liivimaa lääneosas moodustati kolm komisjoni. Pärnu kreisis tegutses komisjon, mille liikmed olid Ernest von Mengden, Bartell Kruhss ja Caspar Pegau. Revisjon algas 13. septembril Häädemeestel, 17. septembril revideeriti Sindit ning 20. septembril Vändrat. Seejärel viidi revisjon läbi Audru piirkonnas, kusjuures Kihnu komisjon viletsate ilmaolude tõttu ei jõudnud. Pärnu piirkonna revisjon lõppes 23. oktoobril Mõisakülas. Selle komisjoni protokolli andmed talupoegade kohta on koondatud tabeliteks.

Viljandi ja Helme lossiläänides toimus revideerimine 15. septembrist kuni 6. oktoobrini. Ka Tarvastu lossiläänis tegutses sama komisjon koosseisus Wolmer Schlippenbach, Ewoldt Fietingkhoff, Dittmer Meyer ja assessor Conradus Betchen. Viljandi ja Helme lossilääni andmed on kirjeldavad ja esitatud jooksva tekstina, kuid üsna samalaadsed Pärnuga.

Põltsamaa piirkonnas kestis revideerimine 27. augustist kuni 27. septembrini ja protokollile kirjutas ülejäänud komisjoni liikmete nimel alla V. Transehe. Laiuse lossiläänis toimus revisjon 29. septembrist kuni oktoobri keskpaigani. Komisjoni koosseis ilmneb protokollist, millele kirjutasid 12. oktoobril alla Magnus v. d. Brincken, V. Transehe ja Salomey Franck. Nende piirkondade kohta on andmed vägagi napid, enamasti on talu kohta antud ainult adramaade arv ja talupoja päritolu.

Põhja-Liivimaa idaosas tegutses neli komisjoni. Esimesse kuulusid maarevident Johann Meerfeldt, Tartu kodanik (hilisem raehärra) Hans Schlottmann ning ilmselt ka Tartu maakohtunik Gotthard Wilhelm Budberg. Selle komisjoni töö Tartumaa lõunapoolses osas võttis aega täpselt ühe kuu - 1638. aasta septembri. Komisjon kontrollis sel ajal 42 mõisat, kuhu kuulus 940 talu. Esimene komisjon alustas tööd 31. augustil Valgjärvel ja lõpetas 1. oktoobril Reolas. Selle aja jooksul ei suutnud revidendid tutvuda iga mõisaga kohapeal, vaid komisjon peatus ühes teeäärses mõisas, kuhu käsutati kokku lähemate mõisate omanikud, ametnikud ning talupojad. Nende tunnistuste põhjal toimus protokolli koostamine ja talude adramaade arvu määramine. Ainult üksikutel juhtudel võis komisjon saadud andmeid kohapeal kontrollida. Seega võib olla kindel, et talupoegade majanduslikku olukorda on näidatud halvemas valguses, kui see tegelikult oli. Vabadikud ja maata inimesed on ilmselt alaregistreeritud. Täpsus

114 Dunsdorfs, Vidzemes arklu revizijas, 282. 
ei olnud sel ajal nii oluline. Andmed pandi kirja lühidalt ja lakooniliselt, püüdes arvestada instruktsiooni ettekirjutusi. ${ }^{115}$

Teise komisjoni kuulusid Tartu maakohtu assessor Carl Stackelberg, Tartu bürgermeister Bartholomaeus Wybers ja Tartu õuekohtu kirjutaja Johannes Adler. See rühm vaatas üle väiksema piirkonna, Kirumpää ja Vastseliina linnuselääni, kus oli kokku 424 talu. Teine komisjon ei märkinud oma protokollides iga mõisa revideerimispäeva, mistõttu võib arvata, et ta tegutses samal moel kui esimene. Revideerimine toimetati septembrikuu jooksul. Võrreldes esimese komisjoniga tähendati andmeid üles kohati üksikasjalikumalt. ${ }^{116}$

Kolmas komisjon, koosseisus assessor Herman Libstorff, Mauritz Gerstorff ja Christoff Langenbrecht, tegutses Liivimaa lätipoolses osas, mistõttu oli loetelus ainult 69 eestlaste poolt asustatud talu keelepiirivaheliselt alalt. See rühm esitas oma töö tulemused tabelina.

Neljas komisjon, liikmeteks Tartu õuekohtu assessor Wilhelm Ulrich, Hans Stralborn ja kirjutaja Daniel Osterlandt, keskendus Tartu piirkonnale: nii Emajõest põhja poole kui ka üle jõe lõuna poole jäävale osale, kus loetleti 17 mõisat ja 448 talu. Revisjon algas 24. augustil Kärknas. Igal järgneval päeval on reisitud uude kohta ja sageli on ühel päeval jõutud revideerida mitut väiksemat mõisat. Sel moel on jõutud veel augustikuu jooksul töö teostada Sootaga, Vara, Vasula, Elistvere, Visusti, Luua, Kuremaa ja mitmes teises mõisas. Septembri alguses revideeriti Saare, Alatskivi, Jõe, Kavastu, Vesneri ja Luunja ning lõpuks 12. septembril veel Haaslava ja 13. septembril Kabina. 9.-10. oktoobril käidi veel läbi viimased väiksed eramõisad Emajõest põhja poole jääval osal. Töötati sarnaselt teiste komisjonidega. Protokollid on põhjalikud ja esitatud tabelitena nagu kolmandal komisjonil, kuigi veidi erinevate jaotustega. ${ }^{117}$

Komisjonide liikmeskond koosnes sel korral juriidiliselt koolitatud inimestest, mitte ainult majanduslike teadmiste ja oskustega ametnikest. Komisjonide kiire töötempo ja täpsete eeskirjade puudumise tõttu ei olnud tulemus päris ühtlane. Kuigi revisjonikomisjonide ülesandeks oli talude majandusliku kandevõime ja adramaade arvu kindlaksmääramine ning erinevate adramaade üleviimine saksa adramaale, jäi viimati mainitud ülesanne sageli täitmata. ${ }^{118}$ Talupoegade ja mõisaomanike käsitused erinesid sageli ja võis arvata, et komisjonid, kuhu kuulusid ka mõisaoma-

\footnotetext{
Liivimaa 1638. a. maarevisjon, XII.

Ibid., XIII.
}

117 Ibid.

118 Ibid. 
nikud, usaldasid rohkem viimati mainitute poolt esitatud arve. Rühmad said töö valmis 1638. aasta oktoobris ning seejärel algas andmete parandamine ja puhtaks kirjutamine, mis kestis kindralkuberneri kantseleis ka veel 1640. aasta alguses.

Kõige keerulisem osa - adramaade kontrollimine ja ühtlustamine - jäi enamasti komisjoni teha. ${ }^{119}$ Adramaa mõiste pidi kajastama talu kandevõimet, mis olenes talu varustatusest tööjõu ja loomadega, aga ka saagikusest. Revisjoni tulemused näitavad, et ülesannet ei täidetud järjekindlalt. Nendes mõisates, kus adramaade ühtlustamine suurteks saksa adramaadeks oleks kaasa toonud adramaade arvu languse, jäeti need ühtlustamata. ${ }^{120}$ Seega peeti adramaade ühtlustamist vähem tähtsaks kui adramaade arvu suurendamist. See näitab, et riigi seisukohast oli kõige tähtsam ratsateenistuskohustuse ja statsiooni suurendamine. Adramaade kokkuvõtlikud arvud muutusid kindralkuberneri kantseleis veel mitmel korral, kuid lõpuks jäädi püsima 4249 adramaa juurde, mis jäi kuni reduktsioonini ametlikult Liivimaa eestlaste poolt asustatud alal haritava maa suuruseks. ${ }^{121}$

Töö lõpptulemus ilmneb 1638. aasta revisjonide protokollidest. ${ }^{122}$ Need annavad hea pildi selle kohta, kuidas Poola aja suured kroonumaad - staarostkonnad - olid läänistatud. Varasem ühtne Tartumaa staarostkond oli jagatud mitmeks osaks, mille lääniõigusest kaks kolmandikku oli antud Rootsi suuraadlile, kes aga oma mõisates ei elanud, vaid valitses neid emamaalt või sõjaväljalt. Revisjonidest ilmneb ka selgelt, kuidas sõdade tõttu kannatada saanud mõisamajandus uuesti õitsele puhkes. Hea ülevaate saab taludest. Ilmneb, et lisaks vanadele taludele oli küladesse tekkinud uusasunikke, kes olid kohale asunud hiljemalt kolm aastat enne revisjoni. Nende mainimise motiiviks oli see, et uusasukad olid kolmeks aastaks maksudest vabastatud. On üsna tavaline, et ära märgiti sisserännanud inimeste päritolu või rahvuslik kuuluvus. Vanad põlistalud moodustasid taludest umbes poole ja nende adramaade arvud erinevad väga suurtes piirides, sest talu kandevõime ei sõltunud ainult maade suurusest, vaid ka tööjõuliste inimeste arvust, veoloomade arvust ning karja suurusest.

119 Dunsdorfs, Vidzemes arklu revīzijas, 281.

120 Tarvel, Adramaa, 115.

121 Liivimaa 1638. a. maarevisjon, XII-XIV.

122 Publitseeritud: Liivimaa 1638. a. maarevisjon, 5-308; Die Revision Livlands 1638, 7-258. Lisaks on 1638. aasta revisjoni kohta olemas lühemaid kokkuvõtteid, nn Kopialbücher ja Extractbücher, vt RA, Östersjöprovinsernas jordrevisionshandlingar, vol. 20-28. Edgars Dunsdorfs on avaldanud 17. sajandi esimese poole Liivimaa maarevisjonide saksakeelsed instruktsioonid ja volitused, vt Dunsdorfs, Vidzemes arklu revizijas, 249-263. 


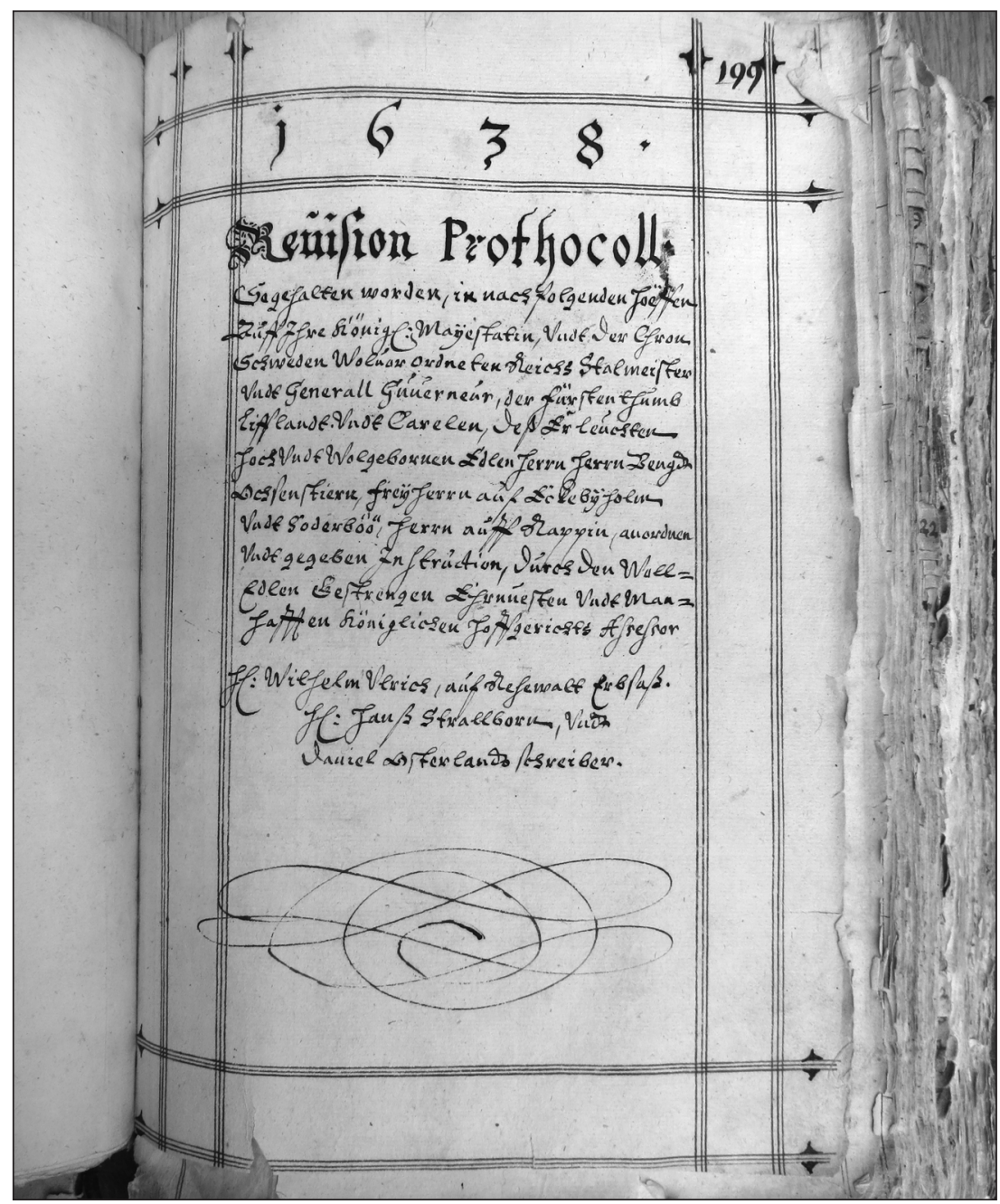

Joonis 1. 1638. aasta Liivimaa revisjoni protokolli esileht (RA, Östersjöprovinsernas jordrevisionshandlingar, vol. 21:3).

1638. aasta revisjon teostati kogu Liivimaal ühel ajal ja rahu tingimustes, mistõttu see on Rootsi võimuperioodi alguse revisjonidest kõige täpsem ja usaldusväärsem. Siiski oli revisjonil puudusi. Veaks on peetud asjaolu, et see tehti "toas laua taga" ja suure kiiruga ning revidendid ei kutsunud enda juurde talupoegi. ${ }^{123}$ Vaatamata puudustele annab see revisjon üle-

123 Leo Leesment, "Edgars Dunsdorfs. Vidzemes arklu revīzijas 1601.-1638. Latvijas Universitātes Raksti. Tautsaimniecības un tiesību zinātnu fakultātes serija IV.1. Latvijas 
vaate Liivimaa haldusliku jaotuse, valdusõiguste, mõisa- ja talumaade suuruse, asustatud ja asustamata talude suhtarvu, talupoegade nimede, nende perekondade, loomade ja koormiste kohta. Seega on revisjon väärtuslikuks allikaks nii administratiivse, sisepoliitilise, õiguslik-sotsiaalse, majandusliku kui ka demograafilise olukorra kohta. 1638. aasta revisjon jäi Liivimaal maksustuse aluseks kuni 1690. aastani, seega pooleks aastasajaks.

Liivimaal viidi revisjon läbi umbes samal ajal, mil Georg von Schwengelnile tehti ülesandeks Pärnu ja Tartu vahelise veetee võimaluse uurimine ja kaardi koostamine. ${ }^{124}$ See oli esimene kord, kui kaardipildile märgiti külasid ja üksiktalusid koos adramaade arvuga või märkusega küla tühjenemise kohta. ${ }^{125}$ Need olid andmed, millele pöörati erilist tähelepanu just revisjonidega seoses. Seega sai alguse revisjonide ja kartograafiliste materjalide koosmäng, kuigi veel üsna piiratud ulatuses.

Problemaatiliseks jääb küsimus, kas ja kuidas puudutas 1638. aasta revisjon Eestimaad. Otto Liivi järgi kestis revisjon Eestimaal kuni 1641. aastani ja selle materjalid olid palju puudulikumad kui Liivimaa osas. ${ }^{126}$ Peale selle Otto Liivi teate ei ole 1638. aasta revisjoni toimumisest Eestimaal mingeid andmeid ja puudub ka revisjoniprotokoll. Tõenäoliselt Eestimaal siiski mingit revisjoni ei toimunud. Küll on aga olemas mõisate kaupa aruandeid, mida mõisaomanikud ja -valitsejad kubermanguvalitsusele saatsid.

\section{Kokkuvõte}

Eesti ala vallutamisel Rootsi riigi poolt oli mitu tagasilööki. Iga kord, kui osa maast oma valdusesse saadi, oli üheks esimeseks administratiivseks meetmeks mõisate ja talude registreerimine. Esmalt püüti saada ülevaade kogu maa-alast varasemate dokumentide, eelkõige vakuraamatute alusel. Nii koostati Eestimaa kohta juba 1564.-65. aastal nn maa- ja maksuraamat, mis andis ülevaate mõisate, külade ja talude ning nende kandevõime ja ka koormiste kohta. Sama toimus ka Liivimaal 1620. aastatel.

Pärast seda, kui olud olid stabiliseerunud, hakati mõtlema revisjoni läbiviimise peale. Revisjonid toimusid kuninga käsul ja vastavate

Universitāte. Riga 1938, 1-288", Ajalooline Ajakiri, 3 (1938), 162-164.

124 Vt Enn Küng, "The plans for making the Pärnu-Viljandi-Tartu waterway navigable in 1630-1680", Ajalooline Ajakiri, 3/4 (2009), 431-432.

125 Tartust lääne poole jääv piirkond 17. sajandil, RA, Kart- och planschsamlingen. Östersjöprovinserna. Livland. Allm. Området väster om Dorpat 160o-talet.

126 Otto Liiv, "Edgars Dunsdorfs, Actus Revisionis Livoniae 1638. Pars Latviae. Fasc. I. Fontes Historiae Latviae. Volumen IV. Editio Institute Historiae Latviae. Riga, 1938", Ajalooline Ajakiri, 3 (1939), 164-165. 
instruktsioonide alusel. Rootsi revisjonidele Eesti- ja Liivimaal oli tüüpiline see, et neid viisid läbi spetsiaalselt selleks moodustatud komisjonid. Komisjonide abil valitsemine oli Rootsis tavaline, kusjuures komisjonid ehk komiteed jagati üldiselt nn selgitavateks ja kontrollivateks komisjonideks (rannsakande komissioner) ning kohtuotsust tegevateks komisjonideks (dömande komissioner). Eesti- ja Liivimaa komisjonid olid esimest tüüpi, sest otsustusvõim kuulus nende töö valmimise järel põhimõtteliselt kuningale või eestkostevalitsusele. Revisjonikomissaride ettepanekutest möödaminek oli siiski haruldane.

Revisjonikomisjoni ülesanded olid enamasti üsnagi laialdased ning esimeste revisjonide üheks olulisemaks osaks oli maaomanike valdusõiguste kontrollimine. Eriti selgelt ilmneb see Eestimaa 1586.-90. aasta revisjoni puhul. Esimeste Liivimaa revisjonide läbiviimise laad ja püstitatud ülesanded sõltusid konkreetsest olukorrast. Sõjaolukorras aastatel 1601, 1617, 1624 ja 1627 toimunud maarevisjonid erinesid tunduvalt pärast maa vallutamist läbiviidud rahuaegsetest revisjonidest 1630. ja 1638. aastal. Ainult need kaks viimast revisjoni katsid kogu Liivimaa.

Komisjoni ülesanded määratleti üldiselt väga laialt ning maarevisjon ja sellega seotud valdusõiguste kontroll oli vaid üks osa komisjoni ülesannetest. Sel põhjusel jäi revisjon sageli pooleli või täielikult sooritamata. Mõnikord võidi revisjoni läbiviimise ülesanne anda hoopis teise ülesande täitmiseks nimetatud komisjonile - nii oli asi ilmselt aastal 1586, kui revisjoni läbiviimine määrati Pljussa jõe relvarahu sõlminud komissaride lisatööks. Harvemini tegeles revisjoni vahetu korraldamisega valitseja, kes oli ise Eesti- või Liivimaal, näiteks hertsog Karl 1601. aastal. Kolmas variant, revisjoni delegeerimine arvukatele alakomisjonidele, oli kasutusel Liivimaal 1638. aastal.

Komisjonide liikmed määrati tavaliselt Rootsi ning Eesti- ja Liivimaa kõrgaadli hulgast. Segakomisjonide kohalikest sakslastest liikmed olid loomulikult Rootsi valitsuse erilised usaldusalused. 1638. aastal koosnesid komisjonid enamasti kohalikest sakslastest ametimeestest, peamiselt juristidest. Komisjonide abil valitsemine jättis tavapärase haldussüsteemi otsustamisest kõrvale.

Tegeliku töö tegid siiski ära komisjoni poolt nimetatud alama taseme ametimehed - sekretärid ja kameriirid. Kohalike olude tundmine on töö tegelikel tegijatel olnud üsna vahelduv (päris kohalikke aadlikke ei tahetudki seda ülesannet täitma panna), kuid tulemuste taset parandasid varasemad majanduslikud dokumendid, abiliste kasutamine ja revisjoniga seotud kubjaste ülekuulamine. Ülekuulamisega sarnaneva meetodi tõttu kasutati revisjonide kohta ka nimetust inkvisitsioon. Paralleelselt revisjoniga toimus mõisate valdus- või kasutamisõiguste kontroll, mis sageli, kuid 
mitte alati, oli poliitiline protsess. Rootsi võimu vastased said karistuse, kannatada saanuid aga tasustati. Kontrollijad sattusid sageli surve alla ja pidasid üksikutes küsimustes kirjavahetust kuninga või kantsleriga. Ilmselt oli viimati mainitute sõnal asja otsustamisel suur kaal. Asjade käik oli sageli selline, et revisjoniga rahulolematud aadlikud pöördusid otse valitseja poole. Kui Gustav II Adolf ja Maria Eleonora 1626. aastal Tallinnas viibisid, käisid mitmed Liivimaa aadlike lesed kuninganna jutul ning neil õnnestuski läänistusotsuseid mõjutada. ${ }^{127}$

Lääniõiguste kontrollimine ei sõltunud revisjonist, vaid oli pidev protsess, mis revisjonide ajal toimus eriti intensiivselt. Vanad läänikirjad ja õigusdokumendid kopeeriti Rootsi ametnike poolt suurtesse koopiaraamatutesse, mida on Eestimaa kohta Rootsi võimu algperioodist säilinud kaheksa ${ }^{128}$ Õiguslikud dokumendid olid aadlile muidugi äärmiselt tähtsad, neid säilitati hoolikalt ja neist tehti vajaduse korral tõendatud koopiaid. Revisjonides viidati neile järjekindlalt.

Emamaa ja provintside majandusolud olid erinevad. Rootsi emamaa poolel saadi andmeid maamaksu ja läänistuste igal aastal koostatud maaraamatutest (jordeböcker), mis muudeti 1630. aastatel korraldatud läänivalitsemise järel osaks lääniarvetest (länsräkenskaper). Maaraamatud olid üsna konservatiivne, aeglaselt muutuv dokumendirühm, sest maksude sissenõudja seisukohalt oli ükskõik, kes makse maksis, peaasi et maksti. Seetõttu on maaraamatu andmed vakuraamatute ja teiste dokumentidega kõrvutades sageli vananenud. ${ }^{129}$ Kuid põhimõtteliselt koostati Rootsis maaraamatuid siiski igal aastal. Eesti- ja Liivimaal läbiviidud revisjonide vahed on aga väga pikad. Iga revisjon sisaldas eelnevast erinevat informatsiooni. Erinevus tulenes sellest, et Läänemere maades ei saanud riik läänistatud aladelt sissetulekut. Vaid poliitilistel murrangu- ja sõjaaegadel ning kohe nende järel kuulus suurem osa taludest riigi maksustamise alla. Aadlike maksutulude kohta riigi esindajad arvet ei pidanud, kuna neist ei laekunud riigile midagi. Piisas, kui ametnikud kontrollisid aeg-ajalt, et aadlikel oli oma valdustele õiguslik alus. Seetõttu toimusid revisjonid pikkade vaheaegade järel.

Kui vaadelda Eesti- ja Liivimaa nelja käsitletud revisjoni, äratab tähelepanu, et need moodustavad teatud mõttes paare. Eestimaa kesksed revisjonid tehti aastatel 1586-90 ja 1601, Liivimaa omad aastatel 1624-27 ja 1638. Mõlema revisjoni vahele mahtus 11 või 12 aastat, esimene revisjon oli tehtud pikema

Arvi Korhonen, Eerikki Antinpoika (Porvoo: WSOY, 1953), 147.

128 Jakob Koit, "Om de estländska kamerala kopieböckerna”.

129 Riksarkivets beståndsöversikt. Del 4. Kammararkivet, 302-305. 
aja jooksul, seevastu hilisem vaid aasta jooksul. Esimene revisjon tehti sõja aegadel, hilisem siis, kui Rootsi võim oli juba kindlustunud. Esimest tehes on raskused olnud eriti suured, hilisem valmis kergemini. Viimased revisjonid olid kohandatud juba mõisamajanduse tarvetele vastavaks.

Varasem kahest revisjonipaarist kirjeldas suures osas aega, mil maa oli alles võetud Rootsi võimu alla ja läänistamisvõimalused olid veel suured. Hilisem peegeldab aga olukorda, mil läänistamine oli peaosas juba toimunud. Uusi revisjone ei olnud seetõttu vaja enne kui 1688. aastal, mil reduktsioon oli olukorda täielikult muutnud. Lisaks tundub, et 1601. ja 1627. aastal püüeldi mingil määral mõlemate kubermangude ühise maksustamise suunas, kuid 1601. aastal jooksis see karile sõjaõnne pöördumise ja 1627. aastal Eestimaal ilmnenud vastupanuvaimu tõttu. Rootsi riik käsitles piirkondi eraldi, nii et revisjoniasjad olid esmalt päevakorras Eestimaal ja alles paar aastakümmet hiljem Liivimaal.

Rootsi kameraalsele valitsemisele avaldas mõju Vasa dünastia valitsejate Gustav Vasa ja Karl IX majanduslik pärand. Vastavalt sellele oli riik huvitatud läänistamata alade talupoegade efektiivsest maksustamisest. Ka Liivimaa kindralkuberneri Johan Skytte eesmärgiks oligi riigi agraartulude kasvatamine ning Liivimaa ja Ingerimaa võimalikult täielik integreerimine Rootsiga.

Vastavalt suurriigiaegsele majandusteadusele, merkantilismile, pidid maaharimisest saadud tulud täitma eelkõige aadlike korraliku ülalpidamise tarvet. See arusaam mõjutas ajuti Rootsi majanduspoliitikat ja oli valitsev aegadel, mil riigis valitses eestkostevalitsus või sisepoliitiliselt nõrk, sõjapoliitikaga seotud kuningas. Kantsler Axel Oxenstierna eelistas hoida Rootsi emamaa ja provintsid teineteisest lahus. See seisukoht ilmneb selgelt 1634. aasta valitsemisvormis, mille alusel valitseti Rootsit kuni absolutismi kehtestamiseni 1680. aastal. Läänemere provintside aadli eriõigused kaitsesid ka Rootsi kõrgaadlit, kel oli seal mõisaomanikena ühtseid eeliseid kohalike aadlikega. Aadlike huvides ei saanudki olla krooni maaõiguste kasvatamine ega riigile maamaksudest saadavate tulude lisandumine, vaid läänisüsteemi pidamine muutumatu ja pärilikuna.

On märkimisväärne, et pärast 1638. aastat ei toimunud ei Eesti- ega Liivimaal ühtegi revisjoni enne 1688.-90. aasta suurt katastrit. See tulenes sellest, et peaaegu kogu maaomand oli läänistatud eraomandiks ja selle tulemusel tekkinud mõisate süsteem stabiilsuse saavutanud. Asustus- ja agraarajaloo allikates on seetôttu Liivimaa osas 50-aastane ja Eestimaa osas veelgi pikem tühimik. 


\section{ABSTRACT: Land revisions in Estland and Livland at the beginning of the Swedish reign}

The article focuses on the ways land revisions were carried out in the provinces of Estland and Livland at the beginning of the Swedish reign and the purposes they served. Land revision data from the Swedish period has been used in numerous studies on Estonian and Latvian settlement and agrarian history. The current picture we have of the structure and changes of the population and settlements, enfeoffments, imposts on peasantry, and agricultural conditions in various regions originates mainly from these sources. The materials on the revisions are kept in the Chamber Archives of the National Archives of Sweden, Historical Archives of the National Archives of Estonia, and the State Archives of Latvia. The revisions done within the territory of Estonia have been published which has notably expanded the scope of their use.

The article pays special attention to the process of carrying out the revisions, temporal framework, methods, people who performed the tasks, but also to the general goals of Swedish economic rule in the Baltic provinces. There were several setbacks in conquering the area for the Swedish crown. Every time a part of the land became a Swedish possession, a swift assessment of the landed property was carried out.

The Swedish crown organized several big revisions at the beginning of its rule in these provinces, namely in Estland from 1586-90 and in Estland and Livland from 1600-01, and additionally in Livland from 1624-27 and in 1638. Apart from these major revisions, there were several other limited revisions that were not completed or the results of which have only partially been preserved (from 1617-19 and in 1630).

Revisions took place on the king's command and according to specific instructions. Land revisions were primarily organized to plan, examine, and specify the state's revenues. The tasks of the revision commission were generally rather broad, and one of the most important obligations during the first revisions was to check the landowners' right of possession. It is especially evident during the revision in Estland from 1586-90. It was typical for Swedish revisions in Estland and Livland to be were carried out by commissions created for that purpose. On rare occasions, the revision was managed by the landlord visiting either Estland or Livland, as was the case with Duke Karl in 1601. The custom of delegating the organization of the revision to numerous sub-commissions was practiced in Livland in 1638 .

Members of the commission were typically appointed from the ranks of the high nobility of Sweden, Estland, and Livland. Mixed commissions 
of Swedes and Germans were common, but the local German members were naturally special trustees to the Swedish government. In 1638, the commissions consisted again mostly of local German officials, primarily lawyers. The real executer of the work was, however, a lower-level official (a secretary or scribe) appointed by the commission. It is clear that the knowledge of those officials about local conditions varied greatly, but the use of previous economic documentation and helpers, and the questioning of taskmasters and peasants improved the level of outcome.

Intervals between revisions in Estland and Livland were very long, and every revision collected different information in comparison with the previous one. The state revenues from agriculture in the Baltics were often limited due to enfeoffment, because only during the time of political turmoil and war and in their immediate aftermath were most of the farmsteads taxed by the state. The state representatives did not keep an account on the tax revenues of the enfeoffed territories. It sufficed when the officials checked from time to time whether the landed property did indeed belong to the nobles who claimed the relevant right.

The revisions in Estland and Livland can be viewed in parallel. The major revisions in Estland took place from 1586-90 and again in 1601, and in Livland from $1624-27$ and in 1638 . The interval between the revisions was 11-12 years, so that the first revision was carried out during a longer period, while the later one only in the course of a single year. The first revisions were organized in the shadow of war, and the latter ones already during the time when Swedish reign was solidified. The earlier revisions surveyed the territory that had only just been conquered by Sweden and the opportunities for enfeoffment were still great. The latter revisions reflect the situation when the enfeoffment had been almost accomplished. It is remarkable that after 1638 there were no revisions in Estland or Livland before the big cadastre of 1688-169o. The reason was that nearly all landed property had been enfeoffed and the system of manors had become stable.

KEYWORDS: Estonian history, province of Estland, province of Livland, history of Sweden, early modern period, agrarian history, payments, land revisions, manors, peasants.

Ülle Tarkiainen (b. 1957) is a Senior Researcher at the Institute of History and Archaeology, University of Tartu.*

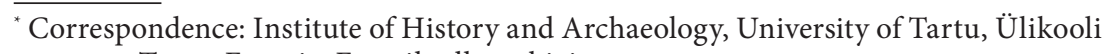
18, 50090 Tartu, Estonia. E-mail: ulle.tarkiainen@ut.ee 